\title{
Costimulation of AMPA and Metabotropic Glutamate Receptors Underlies Phospholipase C Activation by Glutamate in Hippocampus
}

\author{
Hye-Hyun Kim, ${ }^{1,2}$-Kyu-Hee Lee, ${ }^{1,2}$ Doyun Lee, ${ }^{1}$ Young-Eun Han, ${ }^{1,2}$ Suk-Ho Lee, ${ }^{1,2}$ Jong-Woo Sohn, ${ }^{3}$ \\ and Won-Kyung Ho ${ }^{1,2}$ \\ ${ }^{1}$ Department of Physiology and ${ }^{2}$ bioMembrane Plasticity Research Center, Seoul National University College of Medicine, Seoul 110-799, Korea, and \\ ${ }^{3}$ Department of Biological Sciences, Korea Advanced Institute of Science and Technology, Daejeon 305-701, Korea
}

\begin{abstract}
Glutamate, a major neurotransmitter in the brain, activates ionotropic and metabotropic glutamate receptors (iGluRs and mGluRs, respectively). The two types of glutamate receptors interact with each other, as exemplified by the modulation of iGluRs by mGluRs. However, the other way of interaction (i.e., modulation of mGluRs by iGluRs) has not received much attention. In this study, we found that group I mGluR-specific agonist (RS)-3,5-dihydroxyphenylglycine (DHPG) alone is not sufficient to activate phospholipase C (PLC) in rat hippocampus, while glutamate robustly activates PLC. These results suggested that additional mechanisms provided by iGluRs are involved in group I mGluR-mediated PLC activation. A series of experiments demonstrated that glutamate-induced PLC activation is mediated by mGluR5 and is facilitated by local $\mathrm{Ca}^{2+}$ signals that are induced by AMPA-mediated depolarization and L-type $\mathrm{Ca}^{2+}$ channel activation. Finally, we found that PLC and L-type $\mathrm{Ca}^{2+}$ channels are involved in hippocampal mGluR-dependent long-term depression (mGluR-LTD) induced by paired-pulse low-frequency stimulation, but not in DHPG-induced chemical LTD. Together, we propose that AMPA receptors initiate $\mathrm{Ca}^{2+}$ influx via the L-type $\mathrm{Ca}^{2+}$ channels that facilitate mGluR5-PLC signaling cascades, which underlie mGluRLTD in rat hippocampus.
\end{abstract}

Key words: Cav1.2; Cav1.3; confocal imaging; electrophysiology; local calcium; mGluR-LTD

\section{Introduction}

Glutamate is a major excitatory neurotransmitter that activates ionotropic and metabotropic glutamate receptors (iGluRs and mGluRs, respectively). iGluRs are ligand-gated ion channels that mediate fast EPSCs, whereas mGluRs are G-protein-coupled receptors (GPCRs). Regulation of iGluRs by mGluRs was previously suggested to be important for integrative brain function (Doherty et al., 1997; Mannaioni et al., 2001). Surface expression of AMPA receptors are reduced by group I mGluR signaling to induce long-term depression (LTD) of synaptic currents (Lüscher and Huber, 2010), while NMDA currents are potentiated by group I mGluR agonists (Doherty et al., 1997). Impor-

Received Oct. 10, 2014; revised Feb. 4, 2015; accepted March 4, 2015.

Author contributions: W.-K.H. and J.-W.S. designed research; H.-H.K., J.-W.S., and Y.-E.H. performed research;

K.-H.L. and D.L. contributed unpublished reagents/analytic tools; H.-H.K., S.-H.L., and J.-W.S. analyzed data; W.-K.H., H.-H.K., and J.-W.S. wrote the paper.

This work was supported by a grant from the Korean Ministry of Health and Welfare (HI14C1846 to J.-W.S.), by a National Research Foundation grant from the Korean Ministry of Science and Future Planning (2014051826 to W.-K.H.), and by the Brain Korea 21 PLUS Program. We thank Dr. Joo Min Park (Jeju National University) for helpful discussions.

The authors declare no competing financial interests.

Correspondence should be addressed to either of the following: Dr. Jong-Woo Sohn, Department of Biological Sciences, Korea Advanced Institute of Science and Technology, 291 Daehak-ro, Yuseong-gu, Daejeon 305-701, Korea. E-mail: jwsohn@kaist.ac.kr; or Dr. Won-Kyung Ho, Department of Physiology, Seoul National University College of Medicine, 103 Daehak-ro, Jongro-gu, Seoul 110-799, Korea. E-mail: wonkyung@snu.ac.kr.

DOI:10.1523/JNEUROSCI.4208-14.2015

Copyright $\odot 2015$ the authors $\quad 0270-6474 / 15 / 356401-12 \$ 15.00 / 0$ tantly, impaired function of NMDA receptors in pathologic conditions could be reversed by the upregulation of group I mGluRs (Won et al., 2012), suggesting a possibility that this interaction can be applied to develop new therapeutic strategies. Likewise, the regulation of mGluR signaling by iGluRs may also have certain physiological significance, but this possibility has received relatively little attention.

While group I mGluRs (mGluR1 and mGluR5) link glutamatergic neurotransmission to a wide variety of signaling pathways and involve multiple partners (Conn and Pin, 1997), the Gq protein/phospholipase C (PLC)/inositol-3,4,5-triphosphate ( $\left.\mathrm{IP}_{3}\right)$ signal cascades have been considered as the canonical pathway (Abe et al., 1992; Aramori and Nakanishi, 1992). However, independent studies have differed on how PLC is involved in group I mGluR effects. The stimulation of Schaffer collateral (SC)-CA1 neuron synapses activates group I mGluRs to mobilize intracellular $\mathrm{Ca}^{2+}$ by PLC and $\mathrm{IP}_{3}$ signal pathways (Nakamura et al., 1999, 2000; El-Hassar et al., 2011), but $\mathrm{Ca}^{2+}$ release by the group I mGluR agonist (RS)-3,5-dihydroxyphenylglycine (DHPG) was shown to be PLC independent (Sohn et al., 2011). In addition, mGluR-dependent LTD (mGluR-LTD) induced by DHPG occurs independently of PLC/IP ${ }_{3}$-dependent $\mathrm{Ca}^{2+}$ release or protein kinase $\mathrm{C}$ (PKC) activity at the SC-CA1 neuron synapse (Schnabel et al., 1999; Fitzjohn et al., 2001; Mockett et al., 2011), whereas mGluR-LTD at the same synapse induced by synaptic stimulation is dependent on intracellular $\mathrm{Ca}^{2+}$ rise and PKC 
activation (Bolshakov and Siegelbaum, 1994; Oliet et al., 1997; Otani and Connor, 1998). These results suggest that, unlike glutamate, application of DHPG is not sufficient for PLC activation. In agreement, when endoplasmic reticulum-containing spines of CA1 neurons were stimulated at a low frequency using glutamate uncaging, this induced group I mGluR-LTD specific to the stimulated synapse and this LTD was dependent on $\mathrm{Ca}^{2+}$ release (Holbro et al., 2009).

Together, we hypothesized that iGluRs may play a significant role in mGluR-mediated PLC activation. Considering that PLC activity per se is dependent on intracellular $\mathrm{Ca}^{2+}$ concentrations (Ryu et al., 1987), the activation of iGluRs may contribute to group I mGluR-mediated PLC activation possibly by inducing $\mathrm{Ca}^{2+}$ influx directly or indirectly. In this study, we found that AMPA receptors initiate $\mathrm{Ca}^{2+}$ influx through L-type $\mathrm{Ca}^{2+}$ channels that are specifically required for mGluR-mediated PLC activation. Furthermore, we found evidence that this mechanism is crucial for mGluR-LTD in the hippocampus induced by pairedpulse low-frequency synaptic stimulation (PP-LFS).

\section{Materials and Methods}

DNA constructs. The PLC $\delta$-pleckstrin homology domain (PH $\delta$ ) cloned into pEGFP-N1 was obtained from Dr. P. Suh (Ulsan National Institute of Science and Technology, Korea). The $\mathrm{Ca}_{\mathrm{v}} 1.2$ (mouse) cloned into vector pcDNA6/V5-His was purchased from Addgene (plasmid 26572). The vector pcDNA6/V5-His containing $\mathrm{Ca}_{\mathrm{v}} 1.3$ (rat) sequence, which in turn contains exon 42a, was obtained from Dr. D. Lipscombe (Brown University, Providence, RI). Ca 1 1.2-targeting short-hairpin RNA (shRNA) sequence (5'-GCCGAAATTACTTCAATATTTCAAGAGAA TATTGAAGTAATTTCGGC- $3^{\prime}$ ) was designed using the software tool available at the Whitehead Institute for Biomedical Research website (Yuan et al., 2004). The $\mathrm{Ca}_{\mathrm{v}} 1.3$-targeting shRNA sequence (5'-GGAAA CCATTTGACATATTTATTCAAGAGATAAATATGTCAAATGGTTTCC $-3^{\prime}$ ) was purchased from Open Biosystems. The synthesized $\mathrm{Ca}_{\mathrm{v}} 1.2$ and $\mathrm{Ca}_{\mathrm{v}} 1.3$ targeting shRNA oligonucleotides (CosmoGenentech) were ligated into the lentiviral vector pLentiLox3.7 (pLL3.7; Rubinson et al., 2003), which coexpressed monomeric RFP. The pLL3.7 containing luciferase-targeting shRNA sequence (5' ${ }^{\prime}$-TAAGGCTATGAAGAGATAC-3') was used as nontargeting control (NT control; Dharmacon).

Cell culture and transfection. All experiments were performed with the approval of the animal experiment ethics committee at the Seoul National University College of Medicine. Neuron-glia coculture protocol for low-density hippocampal primary culture was previously described (Kaech and Banker, 2006; Lee et al., 2012). Briefly, hippocampi were dissected from embryonic day 18 Sprague Dawley (SD) rats of either sex. Hippocampal neurons were dissociated by papain treatment and trituration, and were plated at a density of $1.1 \times 10^{4}$ cells $/ \mathrm{cm}^{2}$ on poly-Dlysine (Sigma-Aldrich)-coated coverslips (Marienfeld) in serum-based cell culture media. The next day, coverslips were transferred onto glial cell feeder layers cultured for $14 \mathrm{~d}$ in vitro (DIV14) in B-27 (Invitrogen)supplemented Neurobasal A (Invitrogen) media. To prevent proliferation of glial cells, $5 \mu \mathrm{M}$ 1- $\beta$-D-cytosine-arabinofuranoside (AraC; Sigma-Aldrich) was added to the DIV4 cocultured neurons. For Western blotting experiments, hippocampal neurons were plated at a density of $4.4 \times 10^{4}$ cells/ $\mathrm{cm}^{2}$ on a poly-D-lysine-coated culture dish. Primary cultured neurons (DIV4-DIV7) were transfected using a calcium phosphate method (Ryan et al., 2005). The culture media were removed and saved before transfection. Neurons were incubated with fresh Neurobasal A media (2 $\mathrm{ml}$ per $60 \mathrm{~mm}$ culture dish) containing $25 \mathrm{~mm}$ HEPES, pH 7.35. During this time, the DNA/calcium phosphate precipitate was prepared by mixing one volume of PH $\delta$-GFP DNA construct $(1 \mu \mathrm{g})$ alone or with NT control, $\mathrm{shCa}_{\mathrm{v}} 1.2$, or $\mathrm{shCa}_{\mathrm{v}} 1.3$ DNA (5 $\mu \mathrm{g}$ for confocal imaging and $\mathrm{Ca}^{2+}$ measurement; $10 \mu \mathrm{g}$ for Western blotting) in $250 \mathrm{~mm} \mathrm{CaCl}_{2}$ with an equal volume of $2 \times$ HEPES-buffered saline $(280 \mathrm{~mm} \mathrm{NaCl}, 50 \mathrm{~mm}$ HEPES, $1.5 \mathrm{~mm} \mathrm{Na}_{2} \mathrm{HPO}_{4}$, pH 7.1) using a Vortex mixer. The precipitate was allowed to form for $2 \mathrm{~min}$ at room temperature (RT) before being added to the culture. Two hundred microliters of DNA/calcium phos- phate suspensions were added drop-wise to cultured hippocampal neurons. A layer of precipitate became obvious after a 15 min incubation period, when cells were quick-washed once; washed twice for $5 \mathrm{~min}$, with fresh Neurobasal A media added between washings; and returned to the saved culture media.

HEK293 cells were plated at a density of $5 \times 10^{4}$ cells per $100 \mathrm{~mm}$ culture dish and maintained in DMEM (Invitrogen) supplemented with $10 \%$ FBS and $1 \%$ penicillin-streptomycin (PS). HEK293 cells were subcultured before reaching $\sim 80 \%$ confluence. HEK 293 cells at $\sim 30 \%$ confluence were transfected as follows: (1) $5 \mu \mathrm{g}$ of $\mathrm{Ca}_{\mathrm{v}} 1.2$ or $5 \mu \mathrm{g}$ of $\mathrm{Ca}_{\mathrm{v}} 1.3$ alone; (2) $5 \mu \mathrm{g}$ of $\mathrm{Ca}_{\mathrm{v}} 1.2$ or $5 \mu \mathrm{g}$ of $\mathrm{Ca}_{\mathrm{v}} 1.3$ with $5 \mu \mathrm{g}$ of NT control; (3) 5 $\mu \mathrm{g}$ of $\mathrm{Ca}_{\mathrm{v}} 1.2$ or $5 \mu \mathrm{g}$ of $\mathrm{Ca}_{\mathrm{v}} 1.3$ with $5 \mu \mathrm{g}$ of $\mathrm{Ca}_{\mathrm{v}} 1.2$ shRNA or $\mathrm{Ca}_{\mathrm{v}} 1.3$ shRNA, respectively. This transfection used the same calcium phosphate protocol for the primary culture except the medium was not changed before and after adding the DNA/calcium phosphate mixture to the culture. Cultures were maintained in a humidified incubator at $37^{\circ} \mathrm{C}$ in $5 \% \mathrm{CO}_{2}$.

Organitypic slice culture and Sindbis viral transduction system. For slice cultures, postnatal day P7-P9 SD rats of either sex were decapitated and their brains were obtained. The posterior part of the brain was cut into $350-\mu \mathrm{m}$-thick transverse slices using a vibratome (ZERO 1, Dosaka) in ice-cold Eagle's balanced salt solution (EBSS) supplemented with 12.5 mM HEPES. The entorhino-hippocampi were dissected out and cultured using membrane-interface techniques mostly according to a previously described procedure (De Simoni and Yu, 2006). Slices were placed on a porous $(0.4 \mu \mathrm{m})$ membrane (Millicell-CM, Millipore) and fed with a mixture of 50\% MEM, 25\% horse serum, 24\% EBSS, and 1\% PS. Glucose was added to reach a final concentration of $36 \mathrm{~mm}$. The media were changed to serum-free media (Neurobasal-A media with 2\% B-27 supplement, $1 \%$ GlutaMAX-I, $1 \%$ PS, and $5 \mathrm{~mm}$ glucose) with $5 \mu \mathrm{M}$ AraC the day after dissection. The media were changed every $2 \mathrm{~d}$. We used a Sindbis virus system to overexpress $\mathrm{PH} \delta$-GFP in hippocampal organotypic slice cultures. PH $\delta$-GFP was subcloned into SINrep (nsP2S726), a modified Sindbis viral vector that shows attenuated viral-induced cytotoxicity and higher expression levels of the protein of interest in neurons (Kim et al., 2004). The complementary RNAs (cRNAs) were synthesized from the linearized SINrep (nsP2S726)/PH $\delta$-GFP and helper DH-BB (tRNA/ TE12) plasmid DNA, using an in vitro transcription kit (mMessage mMachine, Ambion). BHK21 cells were electroporated with cRNAs of SINrep (nsP2S726)/PH-GFP and DH-BB (tRNA/TE12) according to the Sindbis Expression System manual (Invitrogen). The pseudovirionscontaining media were collected after $48 \mathrm{~h}$, and then cell debris was removed from the supernatant by centrifugation at $1400 \times g$ for $10 \mathrm{~min}$ at $4^{\circ} \mathrm{C}$ and aliquots were stored at $-80^{\circ} \mathrm{C}$. Subsequently, cultured hippocampal slices were infected at 8-15 DIV with titer resulting in infection of $<5 \%$ of neurons for $24 \mathrm{~h}$.

Western blotting. Primary cultured hippocampal neurons or HEK293 cells were harvested after $7 \mathrm{~d}$ or $24 \mathrm{~h}$ of DNA transfection, respectively. The cells were washed once with Dulbecco's PBS (Invitrogen) and solubilized in ice-cold lysis buffer containing $50 \mathrm{~mm}$ Tris-Cl, pH 7.4, $150 \mathrm{~mm}$ $\mathrm{NaCl}, 1 \mathrm{~mm}$ EDTA, $1 \%$ SDS, and $0.1 \%$ protease inhibitor mixture (Sigma-Aldrich). Cell lysates were then sonicated 20 times at $1 \mathrm{~s}$ intervals and denatured by $100^{\circ} \mathrm{C}$ boiling water for $5 \mathrm{~min}$. Cell lysates were clarified by centrifugation at $8200 \times g$ for $1 \mathrm{~min}$ at $4^{\circ} \mathrm{C}$. Cell lysates were separated by SDS-PAGE and transferred onto a polyvinylidene difluoride membrane (Millipore). The resulting blots were blocked for $1 \mathrm{~h}$ in PBS plus $0.1 \%$ Triton X-100 (0.1\% PBST) containing 5\% skim milk (Difco). The blots were incubated overnight at $4^{\circ} \mathrm{C}$ with the following specific primary antibodies: mouse monoclonal anti-Ca 1.2 (1:150; Neuromab), rabbit polyclonal anti-Ca 1.3 (1:100; Alomone Labs), goat polyclonal anti-Ca 1.3 (1:100; Santa Cruz Biotechnology), or goat polyclonal antiGAPDH (1:1500; Santa Cruz Biotechnology) as loading controls. The blots were washed with PBS containing $1 \%$ NP-40 and 0.1\% SDS (washing buffer) for $1 \mathrm{~h}$ and then twice with PBS for $30 \mathrm{~min}$. After washing, the blots were incubated at RT for $1 \mathrm{~h}$ with the corresponding horseradish peroxidase-conjugated secondary antibodies: donkey anti-mouse IgG (1: 2500; Jackson ImmunoResearch), donkey anti-rabbit IgG (1:2000; Abcam), or donkey anti-goat IgG (1:2000; Santa Cruz Biotechnology). The blots were then washed with washing buffer for $30 \mathrm{~min}$ and then twice 
with PBS for 15 min. Detection was performed using enhanced chemiluminescence reagent (GE Healthcare Bio-Sciences) and exposed to $\mathrm{x}$-ray films (Agfa).

Imaging and analysis of $\mathrm{PH} \delta$-GFP translocation. All images were obtained from DIV7-DIV14 cultured neurons. Transfected cells were imaged with a TCS-SP2 (Leica) confocal laser-scanning microscope using a $63 \times$ water-immersion objective (numerical aperture, 1.20; HCX PL APO $63 \times$, Leica) or FV300 (Olympus) using a $63 \times$ water-immersion objective (numerical aperture, 0.9; LUMP-lanFl/IR, Olympus). Fluorochromes were excited with an argon laser at 488 and $543 \mathrm{~nm}$. Appropriate emission filters were used for fluorescence detection. $\mathrm{PH} \delta$-GFP favors phosphatidylinositol 4,5-bisphosphate ( $\mathrm{PIP}_{2}$ ) over phosphatidylinositol, phosphatidylinositol 3-phosphate, and phosphatidylinositol 3,4,5triphosphate, but has $\sim 10$ times higher affinity for $\mathrm{IP}_{3}$ than for $\mathrm{PIP}_{2}$ (Várnai and Balla, 1998). Because of this affinity difference, PIP $_{2}$ hydrolysis by PLC causes $\mathrm{PH} \delta$-GFP to translocate from the plasma membrane to the cytosol. Dissociated hippocampal primary cultures were perfused with normal tyrode solution containing the following (in $\mathrm{mM}$ ): $150 \mathrm{NaCl}$, $5 \mathrm{KCl}, 2 \mathrm{CaCl}_{2}, 1 \mathrm{MgCl}_{2}, 10$ glucose, 10 HEPES, adjusted to $\mathrm{pH} 7.4$ with Tris- $\mathrm{OH}$ while imaging. To make $\mathrm{Ca}^{2+}$-free normal tyrode solutions, $\mathrm{CaCl}_{2}$ was replaced by equimolar $\mathrm{MgCl}_{2}$ and $0.1 \mathrm{~mm}$ EGTA was added. Organotypic hippocampal slice cultures were perfused with artificial CSF (aCSF) containing the following (in $\mathrm{mm}$ ): $124 \mathrm{NaCl}, 26 \mathrm{NaHCO}_{3}, 3.2$ $\mathrm{KCl}, 1.25 \mathrm{NaH}_{2} \mathrm{PO}_{4}, 2.5 \mathrm{CaCl}_{2}, 1.3 \mathrm{MgCl}_{2}, 10$ glucose, $3 \mathrm{Na}$-pyruvate, 3 vitamin $\mathrm{C}$, bubbled with mixture of $95 \% \mathrm{O}_{2}$ and $5 \% \mathrm{CO}_{2}$ to a final $\mathrm{pH}$ of 7.4. To statistically analyze $\mathrm{PH} \delta$-GFP translocation, regions of interest (ROIs) were defined in the cytosol areas of soma or dendrite. Differences in the fluorescence intensity $(\Delta F)$ inside ROIs were obtained and normalized to baseline values $\left(F_{0}\right)$ before first glutamate application (Figs. $1 A-C, 2 C a, C c$; see $5 B, C b)$. The relative $\Delta F$ values were calculated by normalizing $\Delta F$ to the peak values of first glutamate application $\left(\Delta F_{1}\right.$; Fig. $3 A-D$; see Fig. $4 A, B$ ). The $\Delta F_{2} / \Delta F_{1}$ values were obtained by calculating ratio between the $\Delta F$ induced by glutamate plus inhibitors $\left(\Delta F_{2}\right)$ and the $\Delta F$ induced by glutamate only $\left(\Delta F_{1}\right)$.

Calcium measurements in hippocampal primary neurons. DIV7-DIV14 primary cultured hippocampal neurons were loaded by incubation with $2 \mu \mathrm{M}$ Fura-2-acetoxymethyl ester (Fura-2AM) plus 0.01\% Pluronic F-127 in normal tyrode solution for $10 \mathrm{~min}$ at RT then washed for $10 \mathrm{~min}$ to remove excess calcium indicators. For fluorescence excitation, we used a polychromatic light source (xenon-lamp based, Polychrome-IV, TILLPhotonics), which was coupled to the epi-illumination port of an inverted microscope (IX70, Olympus) via a quartz light guide and a UV condenser. Microfluorometry was performed with a $40 \times$ waterimmersion objective (numerical aperture, 1.15; UApo $40 \times \mathrm{W} / 340$, Olympus) and a photodiode (TILL-Photonics). Standard twowavelength protocol was used for fluorescence measurements of cells. Fluorescence intensity at an ROI including the soma was measured at 1 $\mathrm{Hz}$ with double-wavelength excitation at $340 \mathrm{~nm}\left(F_{340}\right)$ and $380 \mathrm{~nm}$ $\left(F_{380}\right)$. The ratio $r=F_{340} / F_{380}$ was converted to $\left[\mathrm{Ca}^{2+}\right]_{\mathrm{i}}$ values according to the following equation: $\left[\mathrm{Ca}^{2+}\right]_{\mathrm{i}}=K_{\text {eff }}\left(R-R_{\min }\right) /\left(R_{\max }-R\right)$, where $K_{\text {eff }}$ was estimated as $0.93 \mu \mathrm{M}$. Calibration parameters were determined by using in vivo calibration (Lee et al., 2000) and estimated $R_{\min }$ and $R_{\max }$ were typically 0.24 and 3.4 , respectively.

Electrophysiological recordings. For electrophysiological recordings, acute hippocampal brain slices were prepared from P16-P19 SD rats of either sex. Following decapitation, the whole brain was immediately removed and submerged in ice-cold aCSF. A vibratome (VT1200S, Leica) was used to prepare transverse hippocampal slices ( $350 \mu \mathrm{m}$ thick). Slices were recovered at $32^{\circ} \mathrm{C}$ for $30 \mathrm{~min}$ and thereafter maintained at RT until used for recordings. Hippocampal CA1 pyramidal cells were visualized using an upright microscope equipped with differential interference contrast optics (BX51WI, Olympus). Electrophysiological recordings were made in somata with EPC-8 amplifier (HEKA Electronik) at a sampling rate of $10 \mathrm{kHz}$. All the recordings were performed at $32 \pm 1^{\circ} \mathrm{C}$ and the rate of aCSF perfusion was maintained at $1-1.5 \mathrm{ml} \mathrm{min}^{-1}$. EPSCs at SC-CA1 synapses were recorded from CA1-PCs in a whole-cell configuration at a holding potential of $-63 \mathrm{mV}$. Patch pipettes $(2-4 \mathrm{M} \Omega$ ) were filled with internal solutions containing the following (in $\mathrm{mm}$ ): 130 potassium gluconate, $7 \mathrm{KCl}, 2 \mathrm{NaCl}, 1 \mathrm{MgCl}_{2}$, 0.1 EGTA, 2 ATP-Mg, 0.3
Na-GTP, 10 HEPES, pH 7.3 with KOH, 295 mosmol $1^{-1}$ with sucrose). Stimulator (Stimulus Isolator A360, WPI) connected to a monopolar electrode filled with aCSF was placed in stratum radiatum of the CA1 field to evoke synaptic responses. The intensity (100 $\mu$ s duration; 5-25 $\mu \mathrm{A}$ ) of extracellular stimulation was adjusted to evoke EPSC amplitudes in the range between 50 and $300 \mathrm{pA}$. After 5-10 min of stabilization from patch break-in, EPSCs were recorded at $0.1 \mathrm{~Hz}$ for $5 \mathrm{~min}$ baseline recordings, which was followed by DHPG application ( $8 \mathrm{~min}$ ) or PP-LFS $(1 \mathrm{~Hz}$, $15 \mathrm{~min}$ ) to induce a mGluR-LTD. The PP-LFS was performed in currentclamp mode. All recordings were performed in the presence of NMDAR antagonists (50 $\mu \mathrm{M} \mathrm{APV})$ to block NMDAR-dependent LTD.

Drugs. DHPG, LY367385, MPEP, CNQX, APV, and $\omega$-conotoxin MVIIC were purchased from Tocris Bioscience. U73122 was from Biomol. Fura-2AM, EGTA-AM, and BAPTA-AM were from Invitrogen. All other drugs were purchased from Sigma-Aldrich. Stock solutions of these drugs were made by dissolution in deionized water or DMSO and were stored at $-20^{\circ} \mathrm{C}$. On the day of the experiment one aliquot was thawed and used. The concentration of DMSO in solutions was maintained at $<0.1 \%$.

Statistical analysis. Data were analyzed using IgorPro (version 4.1, WaveMetrics), OriginPro (version 8.0, Microcal) software, and Fiji-win 32 and are presented as mean \pm SEM, where $n$ represents the number of cells studied. The statistical significance of differences between the peaks was evaluated using a Student's $t$ test with confidence levels of $p<0.01$ $\left.{ }^{* *}\right), p<0.05\left(^{*}\right)$ and $p>0.05$ (not significant).

\section{Results}

\section{Glutamate, but not DHPG, induces robust PLC activation in} hippocampal neurons

The intracellular signaling cascades elicited by DHPG application were independent of PLC in previous studies (Schnabel et al., 1999; Fitzjohn et al., 2001; Ireland and Abraham, 2002; Sohn et al., 2007, 2011; Mockett et al., 2011). In addition, it is suspected that the apparent PLC independence of mGluR-LTD may be due to the use of DHPG to induce LTD instead of more physiological methods (Lüscher and Huber, 2010). Thus, we directly tested the idea that the ability to activate PLC may be different between DHPG and glutamate (the latter of which is released by fiber stimulation). To this end, we used $\mathrm{PH} \delta$-GFP constructs to visualize PLC activation, as described previously (Gamper et al., 2004; Horowitz et al., 2005).

We transfected primary cultured dissociated hippocampal neurons with $\mathrm{PH} \delta$-GFP construct (see Materials and Methods), and confirmed preferential localization of fluorescent signals at the plasma membrane (single-cell culture, Control; Fig. 1Aa). Interestingly, the application to the bath solutions of $(R S)-3,5$ DHPG $(50 \mu \mathrm{M})$, a specific group I mGluR agonist, did not induce discernable PH $\delta$-GFP translocation (DHPG: $\Delta F / F_{0}=0.04 \pm$ $0.03, n=10)$, whereas glutamate $(30 \mu \mathrm{M})$ caused a robust translocation of $\mathrm{PH} \delta$-GFP into the cytosol in the same population (Glu: $\Delta F / F_{0}=0.47 \pm 0.12, n=10, p<0.01$; Fig. $1 A a, A b$ ). Line profiles of fluorescence intensity demonstrated that the cytosolic fluorescence, which reflects the generation of $\mathrm{IP}_{3}$, remained unchanged with DHPG treatment, but was significantly increased by glutamate treatment (Fig. $1 A a$, insets). To rule out the possibility that these observations are limited to dissociated hippocampal neurons, we repeated similar series of experiments in hippocampal slices. In organotypic slice culture systems, we confirmed that glutamate, but not DHPG, induced PH $\delta$-GFP translocation in the same population (DHPG: $\Delta F / F_{0}=0.05 \pm 0.02$, $n=6$; Glu: $\Delta F / F_{0}=0.57 \pm 0.13, n=7, p<0.01$; Fig. $\left.1 A a, A b\right)$. Thus, our results suggest that stimulation of group I mGluR alone is not sufficient to activate PLC in hippocampal neurons. 
Aa

Single cell culture

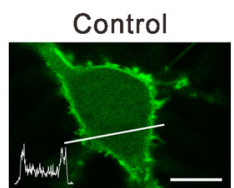

Slice culture

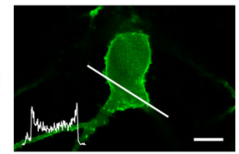

$\mathrm{Ba}$

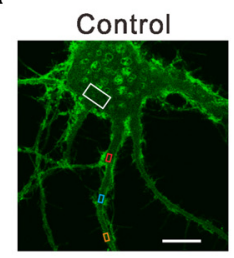

C
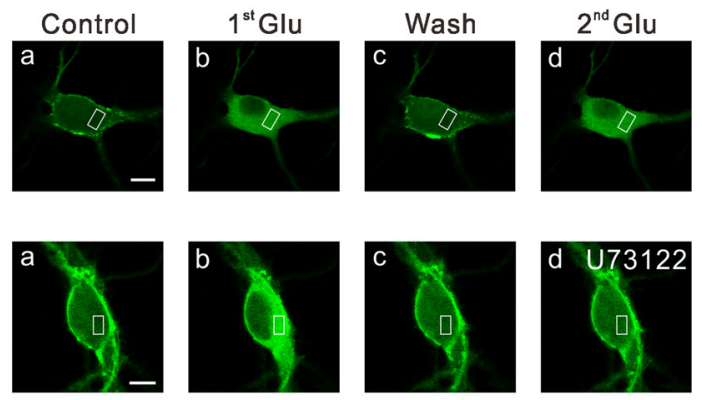

D
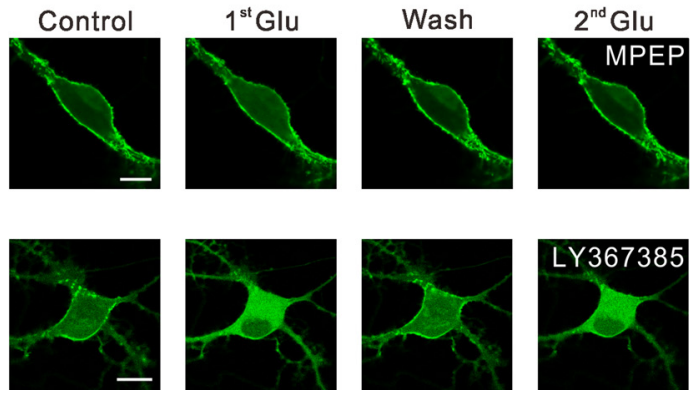

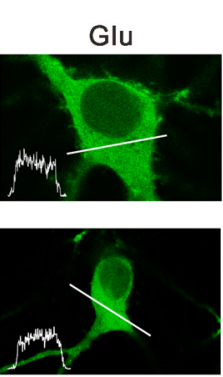

Ab

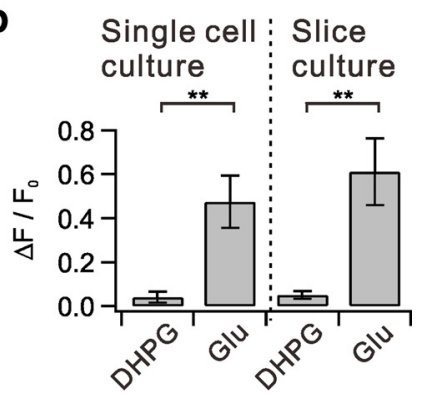

Bc
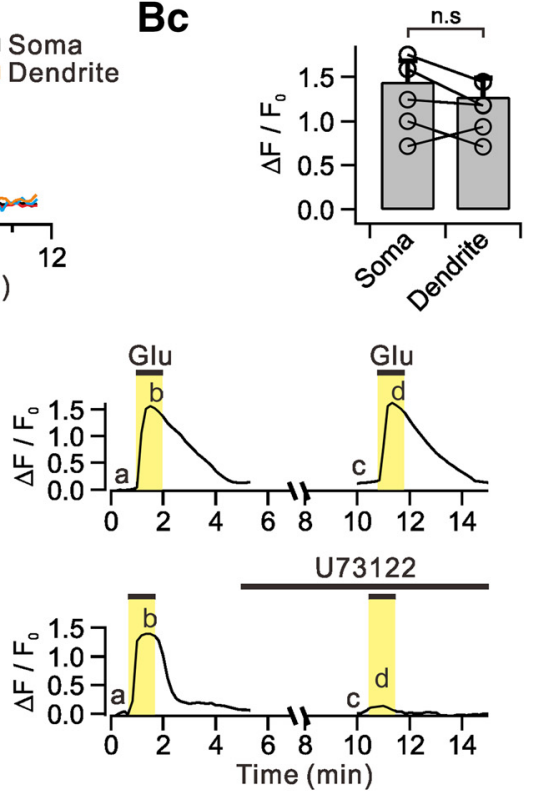

E

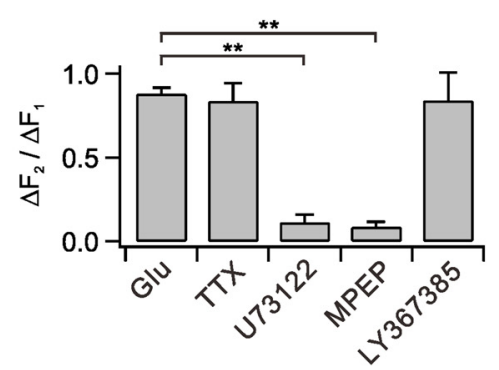

Figure 1. Glutamate, but not DHPG, induces translocation of PH $\delta$-GFP via the mGluR5-PLC pathways. Aa, Dissociated hippocampal neurons in primary culture (single-cell culture) transfected with PH $\delta$-GFP showed prominent green fluorescence signals in plasma membrane versus cytosol (Control). DHPG and glutamate (Glu) was applied to bath to see whether they induce PH $\delta$-GFP translocation. Line profiles of fluorescence intensity (insets) were obtained across the white lines. Similar series of experiments were performed with hippocampal neurons in organotypic slice culture transfected with PH $\delta$-GFP. $\boldsymbol{A} \boldsymbol{b}$, Summary data showing the relative amplitudes of DHPG-induced and glutamate-induced PH $\delta$-GFP translocation $\left(\Delta F / F_{0}\right)$ in single-cell and slice culture conditions. $\boldsymbol{B} \boldsymbol{a}$, Glutamate-induced PH $\delta$-GFP translocation $\left(\Delta F / F_{0}\right)$ was measured in ROls of somatic cytosol (white) and multiple regions of dendritic cytosol (red, blue, and orange). $\boldsymbol{B} \boldsymbol{b}$, Time courses of $\Delta F / F_{0}$ measured in designated ROIs. BC, Bar graphs summarize the amplitudes of DHPG-induced or glutamate-induced PH $\delta$-GFP translocation in soma and dendrites. $C$, Consecutive applications of $30 \mu \mathrm{m}$ glutamate in control and in the presence of U73122. Images of PH $\delta$-GFP-transfected neurons (left) and time courses of $\Delta F / F_{0}$ measured in designated ROIs (right). $\boldsymbol{D}$, Effect of specific blockers for mGluR5 or mGluR1 on PH $\delta$-GFP translocation. $E$, Bar graphs summarize $\Delta F_{2} / \Delta F_{1}$ in the presence of tetrodotoxin (TTX) and other experimental conditions described in $C$ and D. n.s $p>0.05 ;{ }^{* *} p<0.01$. Scale bar, $10 \mu \mathrm{m}$ in all panels where indicated. Error bars represent SEM.

\section{Glutamate stimulates mGluR5 to activate PLC in} hippocampal neurons

Glutamate-induced translocation of $\mathrm{PH} \delta$-GFP was observed in multiple regions of the proximal dendrites (Fig. $1 B a, B b$ ), and these were not significantly different from those observed in the soma (soma: $\Delta F / F_{0}=1.44 \pm 0.24$; dendrite: $\Delta F / F_{0}=1.28 \pm$ $0.21, n=6, p>0.05$; Fig. $1 B c$ ). The increase in cytosolic fluorescence by glutamate was reliably repeated with similar magnitude when glutamate was reapplied after a $\sim 10 \mathrm{~min}$ interval $\left(\Delta F_{2} / \Delta F_{1}\right.$ $=88.0 \pm 3.6 \%, n=10$; Fig. $1 C, E)$. For some experiments, we added tetrodotoxin $(1 \mu \mathrm{M})$ in the bath solution before second glutamate application to block action potential-dependent events, and glutamate still induced reliable translocation of $\mathrm{PH} \delta$ GFP $\left(\Delta F_{2} / \Delta F_{1}=83.6 \pm 10.8 \%, n=5, p>0.05\right.$; Fig. $\left.1 E\right)$. The glutamate-induced translocation of PH $\delta$-GFP was significantly inhibited by PLC inhibitor U73122 ( $1 \mu \mathrm{M} ; \Delta F_{2} / \Delta F_{1}=8.6 \pm 3.1$, $n=4, p<0.01$; Fig. $1 C, E)$ and $25 \mu \mathrm{M}$ MPEP, a specific mGluR5 blocker $\left(\Delta F_{2} / \Delta F_{1}=11.2 \pm 4.8 \%, n=4, p<0.01\right.$; Fig. $\left.1 D, E\right)$, but it was not affected by LY367385 $(100 \mu \mathrm{M})$, a specific mGluR1 blocker $\left(\Delta F_{2} / \Delta F_{1}=84.1 \pm 16.7 \%, n=5, p>0.05\right.$; Fig. $\left.1 D, E\right)$. 
Aa
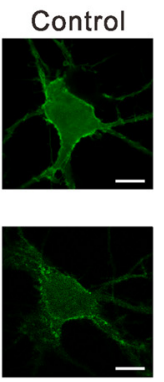

$\mathrm{Ba}$
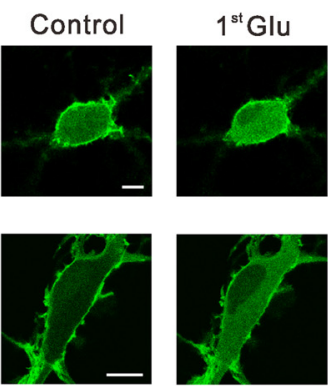

Ca
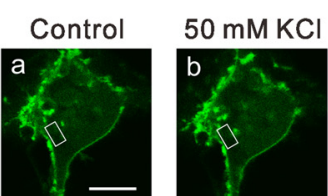

$50 \mathrm{mMKC}$

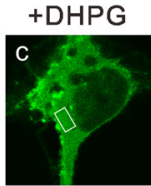

$50 \mathrm{mM} \mathrm{KCl}$

$50 \mathrm{mM} \mathrm{KCl}$
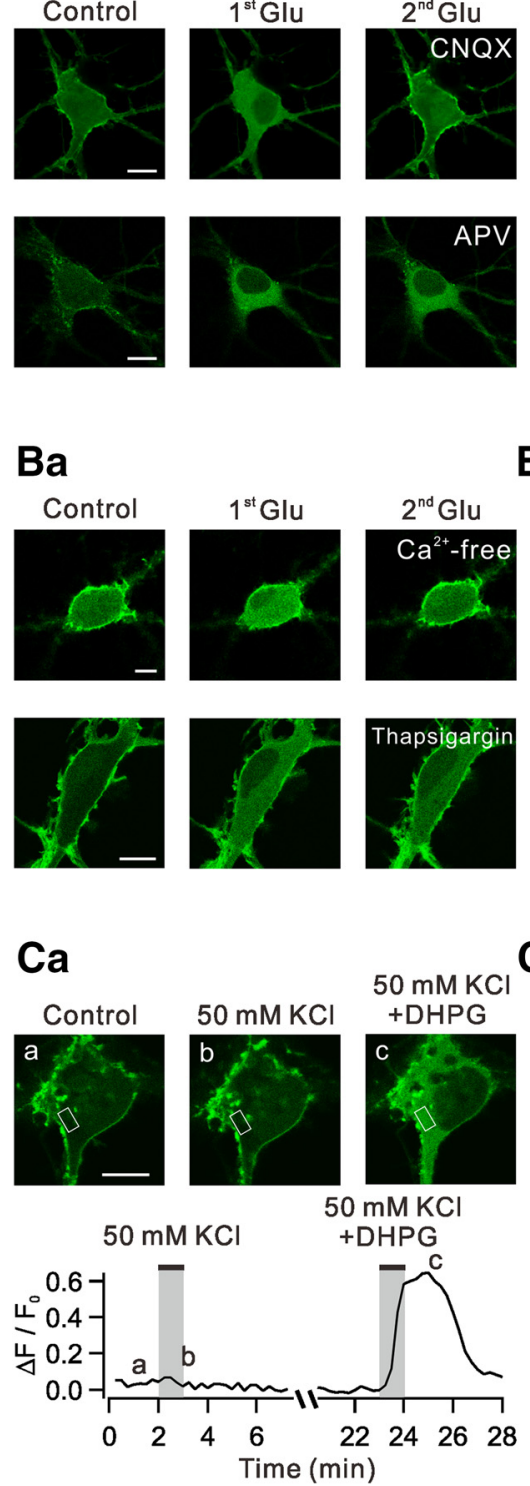

$A b$
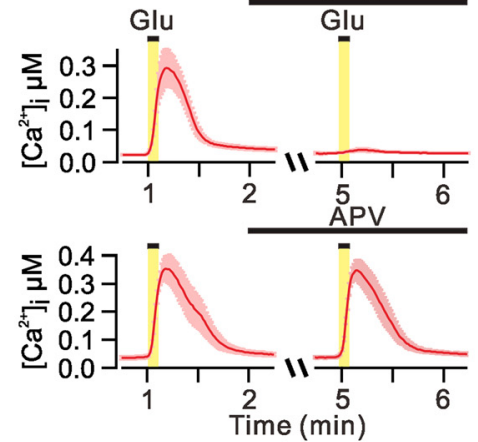

$\mathrm{Bb}$
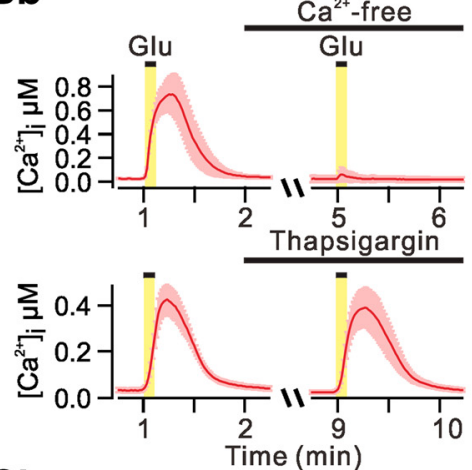

$\mathrm{Cb}$

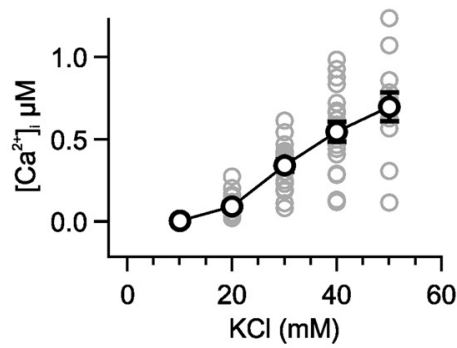

Ac

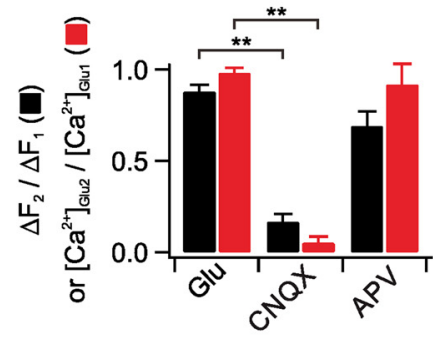

Bc

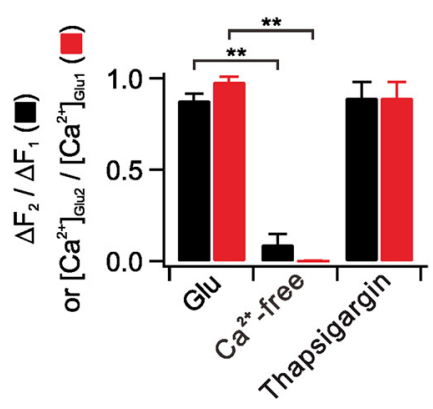

Cc

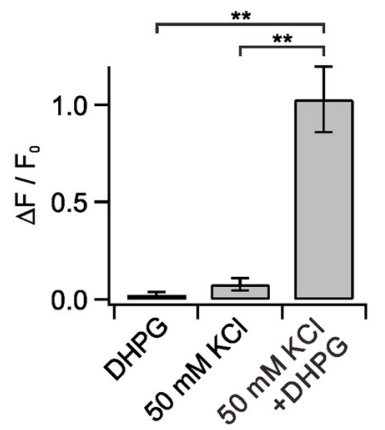

Figure 2. $\quad \mathrm{Ca}^{2+}$ influx triggered by AMPA receptor activation facilitates glutamate-induced PH $\delta$-GFP translocation. $A \boldsymbol{a}$, Images demonstrate glutamate-induced translocation of PH $\delta$-GFP in the presence of CNQX (AMPA receptor blocker) and APV (NMDA receptor blocker). $\boldsymbol{A} \boldsymbol{b}$, Glutamate-induced $\left[\mathrm{Ca}^{2+}\right]_{i}$ in the presence of CNQX and APV. Error bars are shown in light colors. Ac, Bar graphs summarize mean $\Delta F_{2} / \Delta F_{1}$ (black) and $\left[\mathrm{Ca}^{2+}\right]_{G \text { lu2 }} /\left[\mathrm{Ca}^{2+}\right]_{\mathrm{Glu} 1}$ (red). Ba, Images demonstrate glutamate-induced translocation of PH $\delta$-GFP in $\mathrm{Ca}^{2+}$-free solutions or in the presence of thapsigargin (a sarco-endoplasmic reticulum $\mathrm{Ca}^{2+}$-ATPase blocker). $\boldsymbol{B} \boldsymbol{b}$, Glutamate-induced $\left[\mathrm{Ca}^{2+}\right]_{\mathrm{i}}$ in experimental conditions described in $\boldsymbol{B a}$. $\boldsymbol{B} \boldsymbol{c}$, Bar graphs summarize mean $\Delta F_{2} / \Delta F_{1}$ (black) and $\left[\mathrm{Ca}^{2+}\right]_{\mathrm{Glu2} 2} /\left[\mathrm{Ca}^{2+}\right]_{\mathrm{Glu} 1}$ (red). Ca, Images of PH $\delta$-GFP translocation induced by $50 \mathrm{~mm} \mathrm{KCl}$ only or $50 \mathrm{~mm} \mathrm{KCl}$ plus DHPG (top) and time courses of $\Delta F / F_{0}$ measured in designated ROls (bottom). Cb, Plot of $\left[\mathrm{Ca}^{2+}\right]_{\mathrm{i}}$ versus different concentrations of $\mathrm{KCl}$. Gray circles represent individual data. $\mathbf{C}, \Delta F / F_{0}$ values are summarized in bar graph in experimental conditions described in $\mathbf{C a} .{ }^{* *} p<0.01$. Scale bar, $10 \mu \mathrm{m}$ in all panels where indicated. Error bars represent SEM.

These results demonstrate that glutamate-induced translocation of $\mathrm{PH} \delta$-GFP is independent of action potential firing and occurs via the activation of mGluR5 and PLC.

$\mathrm{Ca}^{2+}$ influx via AMPA receptor activation is required for PLC activation by glutamate

Given the differential effects of DHPG and glutamate, we suspected that glutamate may provide additional signaling mechanisms required for PLC activation via iGluRs. To test this idea, we examined the contribution of iGluRs using $10 \mu \mathrm{M}$ CNQX or 50 $\mu \mathrm{M}$ APV, specific antagonists for AMPA receptors and NMDA receptors, respectively. As shown in Figure $2 A \mathrm{a}, A c$, glutamateinduced translocation of $\mathrm{PH} \delta$-GFP was blocked by CNQX $\left(\Delta F_{2} /\right.$ $\left.\Delta F_{1}=16.8 \pm 4.2 \%, n=5, p<0.01\right)$, but it was not significantly affected by $\operatorname{APV}\left(\Delta F_{2} / \Delta F_{1}=69.3 \pm 8.0 \%, n=5, p>0.05\right)$. We also found that glutamate-induced translocation of $\mathrm{PH} \delta$-GFP was completely suppressed in $\mathrm{Ca}^{2+}$-free bath solutions $\left(\Delta F_{2} / \Delta F_{1}\right.$ $=9.0 \pm 5.9 \%, n=6, p<0.01)$, but it was not significantly affected by $2 \mu \mathrm{M}$ thapsigargin $\left(\Delta F_{2} / \Delta F_{1}=89.6 \pm 8.5 \%, n=4\right.$, $p>0.05)$, which suggested a role of $\mathrm{Ca}^{2+}$ influx, but not $\mathrm{Ca}^{2+}$ mobilization (Fig. $2 \mathrm{Ba}, \mathrm{Bc}$ ). Thus, our results suggest that $\mathrm{Ca}^{2+}$ entry triggered by AMPA receptor activation may contribute to mGluR5-mediated PLC activation.

In a separate series of experiments, we characterized glutamate-induced $\mathrm{Ca}^{2+}$ transients $\left(\left[\mathrm{Ca}^{2+}\right]_{\mathrm{i}}\right)$ to identify $\mathrm{Ca}^{2+}$ sources required for PLC activation by mGluR5 in primary cultured dissociated hippocampal neurons loaded with $2 \mu \mathrm{M}$ Fura2AM. Bath applications of glutamate $(30 \mu \mathrm{M})$ caused a rapid 
A

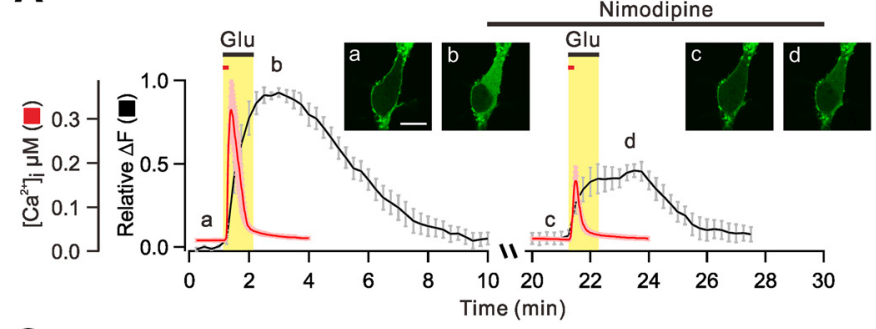

C

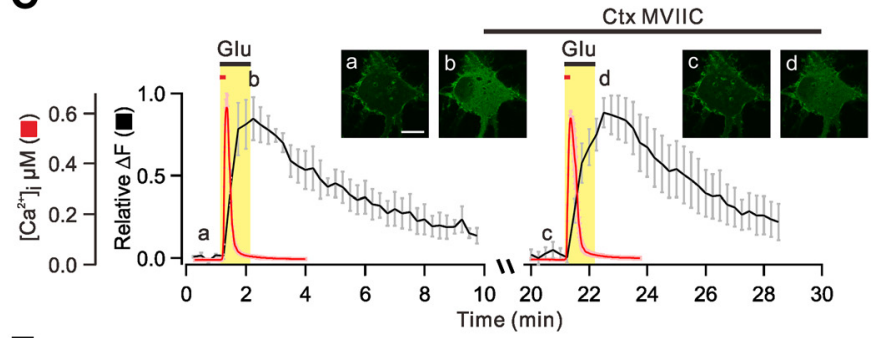

$\mathbf{E}$

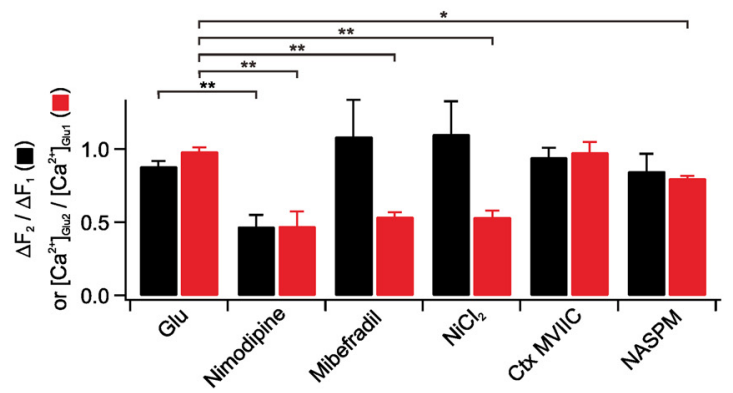

B

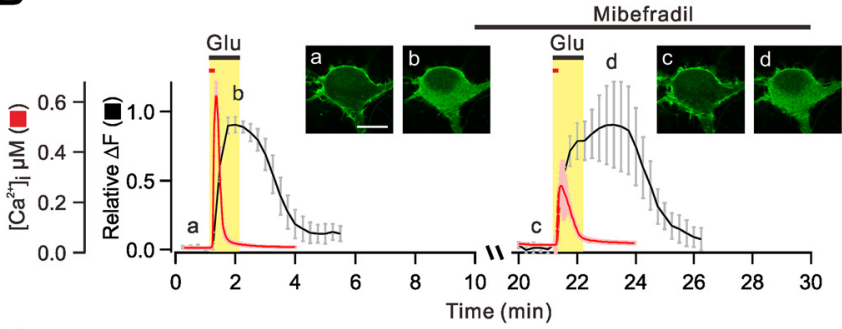

D

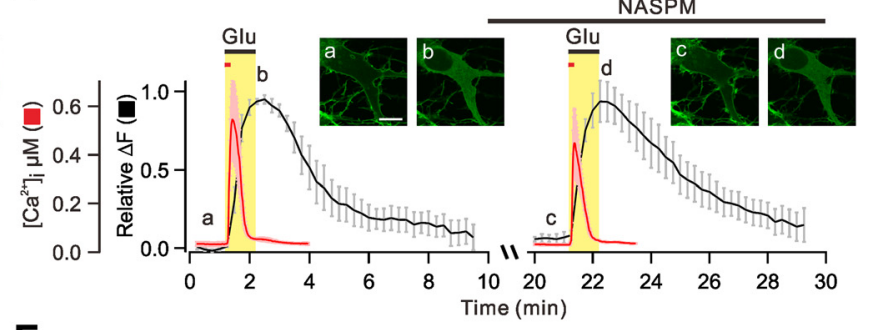

$\mathbf{F}$

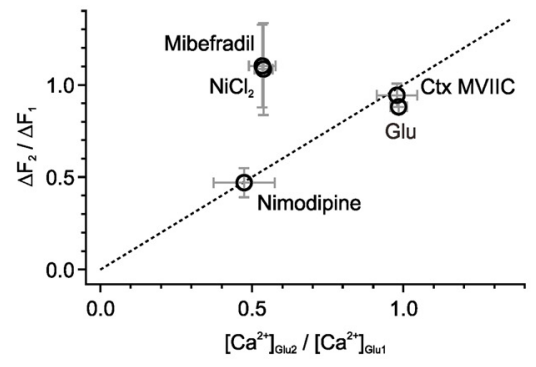

Figure 3. L-type $\mathrm{Ca}^{2+}$ channels provide $\mathrm{Ca}^{2+}$ for glutamate-induced PH $\delta$-GFP translocation. $\boldsymbol{A}-\boldsymbol{D}$, Averages of glutamate-induced $\left[\mathrm{Ca}^{2+}\right]_{\mathrm{i}}($ red $)$ and relative $\Delta F($ black) are plotted against time for two successive applications of glutamate (first applications are glutamate only, and second applications are glutamate plus L-type, T-type, or N/P/Q-type Ca ${ }^{2+}$ channel blockers, or $\mathrm{Ca}^{2+}$-permeable AMPA receptor blocker). The time intervals of first and second glutamate applications are actual values $(20 \mathrm{~min})$ for $\Delta F$, but for $\left[\mathrm{Ca}^{2+}\right]_{\mathrm{i}}$ measurements the time intervals were 4 $\mathrm{min}$, as described in Figure $2 A b$ : they were superimposed for comparison of time-dependent events. The insets show representative images of PH $\delta$-GFP translocation at indicated time points (a- $d$ ). Scale bar, $10 \mu \mathrm{m}$. $\boldsymbol{E}$, Bar graphs summarize mean $\Delta F_{2} / \Delta F_{1}\left(\right.$ black) and $\left[\mathrm{Ca}^{2+}\right]_{G l u 2} /\left[\mathrm{Ca}^{2+}\right]_{G l u 1}\left(\right.$ red). $\boldsymbol{F}, \Delta F_{2} / \Delta F_{1}$ values are plotted versus $\left[\mathrm{Ca}^{2+}\right]_{G l u 2} /\left[\mathrm{Ca}^{2+}\right]_{G l u 1}$ values. Dashed line indicates linear relationship. ${ }^{* *} p<0.01 ;{ }^{*} p<0.05$. Error bars represent SEM.

increase in $\left[\mathrm{Ca}^{2+}\right]_{\mathrm{i}}$ with an average amplitude of $438 \pm 27 \mathrm{nM}$ $(n=67)$. We found that glutamate-induced $\left[\mathrm{Ca}^{2+}\right]_{\mathrm{i}}$ increase was completely suppressed in $\mathrm{Ca}^{2+}$-free bath solution $\left(\left[\mathrm{Ca}^{2+}\right]_{2} /\right.$ $\left.\left[\mathrm{Ca}^{2+}\right]_{1}=0.22 \pm 0.1 \%, n=4, p<0.01\right)$, but it is not affected by $2 \mu \mathrm{M}$ thapsigargin $\left(\left[\mathrm{Ca}^{2+}\right]_{2} /\left[\mathrm{Ca}^{2+}\right]_{1}=89.5 \pm 8.5 \%, n=4, p>\right.$ 0.05 ; Fig. $2 \mathrm{Bb}, \mathrm{Bc})$, indicating that the glutamate-induced $\left[\mathrm{Ca}^{2+}\right]_{\mathrm{i}}$ increase is mostly mediated by $\mathrm{Ca}^{2+}$ influx, but not by $\mathrm{Ca}^{2+}$ release in cultured hippocampal neurons. We also confirmed that CNQX profoundly inhibits glutamate-induced $\left[\mathrm{Ca}^{2+}\right]_{\mathrm{i}}$ $\left(\left[\mathrm{Ca}^{2+}\right]_{2} /\left[\mathrm{Ca}^{2+}\right]_{1}=5.3 \pm 3.4 \%, n=5, p<0.01\right)$, but APV has no effect $\left(\left[\mathrm{Ca}^{2+}\right]_{2} /\left[\mathrm{Ca}^{2+}\right]_{1}=92.0 \pm 11.1 \%, n=5, p>0.05\right.$; Fig. $2 A b, A c)$. These results suggest that AMPA receptors, but not NMDA receptors, are largely responsible for the $\mathrm{Ca}^{2+}$ influx by glutamate. Given the calcium dependence of PLC activity (Ryu et al., 1987; Rebecchi and Pentyala, 2000), AMPA receptormediated depolarization and subsequent $\mathrm{Ca}^{2+}$ influx via voltagegated $\mathrm{Ca}^{2+}$ channels (VGCCs) may facilitate PLC activation by mGluR5.

To test whether the opening of VGCCs independent of AMPA receptor stimulation can facilitate PLC activation by mGluR5, we elevated external $\mathrm{K}^{+}$concentration from 5 to $50 \mathrm{~mm}$. We added CNQX $(10 \mu \mathrm{M})$ to the bath solution for these experiments so that we may exclude the contribution of AMPA receptor-mediated depolarization by glutamate that is released from presynaptic terminals in high- $\mathrm{K}^{+}$conditions. Under this experimental condition, $50 \mathrm{~mm} \mathrm{KCl}$ alone increased $\left[\mathrm{Ca}^{2+}\right]_{\mathrm{i}}$ to $697 \pm 86 \mathrm{nM}(n=$
12), but had no effects on $\mathrm{PH} \delta$-GFP translocation $\left(\Delta F / F_{0}=\right.$ $0.08 \pm 0.03, n=5$; Fig. $2 C a-C c)$. When we added DHPG to 50 $\mathrm{mM} \mathrm{KCl}$, it robustly induced $\mathrm{PH} \delta$-GFP translocation $\left(\Delta F / F_{0}=\right.$ $1.03 \pm 0.2, n=10, p<0.01$; Fig. $2 C a, C c)$. These findings further support the idea that $\mathrm{Ca}^{2+}$ influx through VGCCs is required for PLC activation by mGluR5.

Both L-type and T-type $\mathrm{Ca}^{2+}$ channels mediate $\mathrm{Ca}^{2+}$ influx, but only $\mathrm{L}$-type $\mathrm{Ca}^{2+}$ channels contribute to PLC activation We used specific $\mathrm{Ca}^{2+}$ channel blockers to identify specific $\mathrm{Ca}^{2+}$ channel subtypes that mediate $\mathrm{Ca}^{2+}$ influx and contribute to PLC activation. We found that glutamate-induced $\left[\mathrm{Ca}^{2+}\right]_{\mathrm{i}}$ is significantly inhibited when pretreated with nimodipine $(10 \mu \mathrm{M})$, an L-type $\mathrm{Ca}^{2+}$ channel blocker $\left(\left[\mathrm{Ca}^{2+}\right]_{2} /\left[\mathrm{Ca}^{2+}\right]_{1}=47.4 \pm\right.$ $10.1 \%, n=7, p<0.01$; Fig. $3 A, E)$. Consistent with the effects on $\mathrm{Ca}^{2+}$ influx, $10 \mu \mathrm{M}$ nimodipine significantly blocked increase of cytosolic fluorescence $\left(\Delta F_{2} / \Delta F_{1}=47.1 \pm 7.9 \%, n=5, p<0.01\right.$; Fig. $3 A, E)$. We confirmed that a lower concentration $(1 \mu \mathrm{M})$ of nimodipine inhibited $\left[\mathrm{Ca}^{2+}\right]_{\mathrm{i}}$ or $\mathrm{PH} \delta$-GFP translocation to a similar extent $\left(\left[\mathrm{Ca}^{2+}\right]_{2} /\left[\mathrm{Ca}^{2+}\right]_{1}=44.1 \pm 6.2 \%, n=7, p<0.01\right.$; $\left.\Delta F_{2} / \Delta F_{1}=52.9 \pm 7.9 \%, n=5, p<0.01\right)$. We also confirmed that $10 \mu \mathrm{M}$ nimodipine significantly inhibits increase of cytosolic fluorescence in the proximal dendrite as well (data not shown).

Mibefradil $(5 \mu \mathrm{M})$, a T-type $\mathrm{Ca}^{2+}$ channel blocker, also significantly inhibited the glutamate-induced $\left[\mathrm{Ca}^{2+}\right]_{\mathrm{i}}\left(\left[\mathrm{Ca}^{2+}\right]_{2} /\right.$ $\left[\mathrm{Ca}^{2+}\right]_{1}=53.8 \pm 3.0 \%, n=9, p<0.01$; Fig. $\left.3 B, E\right)$. In addition, 
A

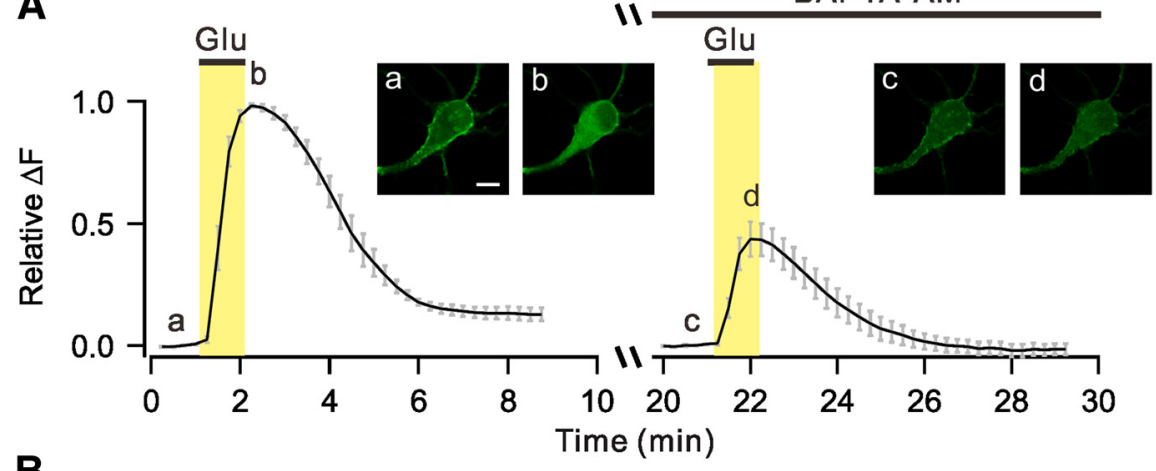

B

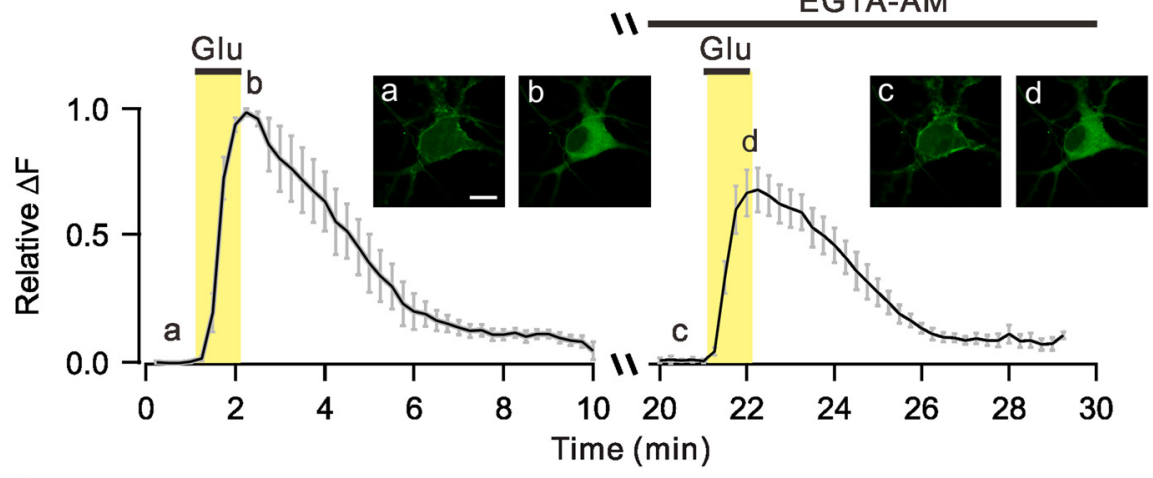

C

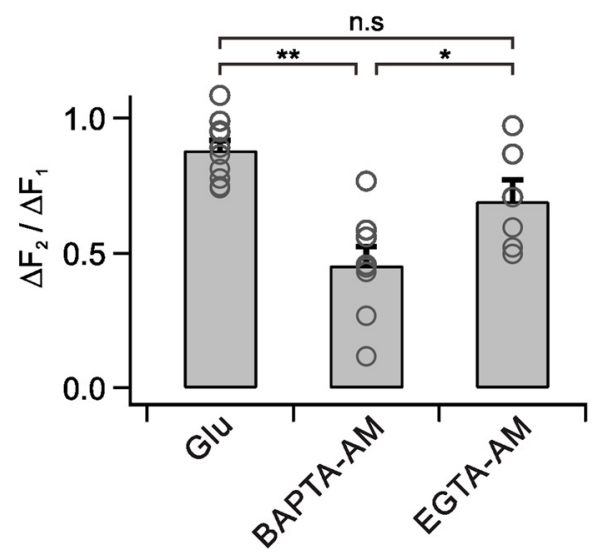

Figure 4. BAPTA, but not EGTA, inhibits glutamate-induced PH $\delta$-GFP translocation. $\boldsymbol{A}-\boldsymbol{B}$, Averages of glutamate-induced relative $\Delta$ Fare plotted against time with BAPTA-AM $(\boldsymbol{A})$ or EGTA-AM $(\boldsymbol{B})$ loadings before second glutamate applications. The insets show representative images of $\mathrm{PH} \delta$-GFP translocation at indicated time points (a-d). Scale bar, $10 \mu \mathrm{m}$. C, Bar graphs summarize mean $\Delta F_{2} / \Delta F_{1}$ in experimental conditions described in $A$ and $B$. n.s $p>0.05 ;{ }^{* *} p<0.01 ;{ }^{*} p<0.05$. Error bars represent SEM.

induced $\left[\mathrm{Ca}^{2+}\right]_{\mathrm{i}}\left(\left[\mathrm{Ca}^{2+}\right]_{2} /\left[\mathrm{Ca}^{2+}\right]_{1}=\right.$ $80.0 \pm 1.7 \%, n=4, p<0.05)$, but had no effect on $\mathrm{PH} \delta$-GFP translocation $\left(\Delta F_{2} /\right.$ $\Delta F_{1}=84.9 \pm 11.7 \%, n=6, p>0.05$; Fig. $3 D, E)$.

We found that most glutamate-induced $\mathrm{Ca}^{2+}$ influx is mediated by L-type and T-type $\mathrm{Ca}^{2+}$ channels, but $\mathrm{Ca}^{2+}$ influx through the L-type $\mathrm{Ca}^{2+}$ channels exclusively contributes to PLC activation by mGluR5 stimulation. Thus, the contribution of each $\mathrm{Ca}^{2+}$ source (L-type and T-type $\mathrm{Ca}^{2+}$ channels) to global $\mathrm{Ca}^{2+}$ transients is not proportional to its contribution to PLC activation (Fig. 3F). These findings suggest that PLC activation by glutamate is not regulated by global $\mathrm{Ca}^{2+}$, but by local $\mathrm{Ca}^{2+}$. Therefore, it can be hypothesized that $\mathrm{Ca}^{2+}$ sensors involved in mGluR5-induced PLC activation is localized very closely to the L-type $\mathrm{Ca}^{2+}$ channels.

BAPTA, but not EGTA, inhibits PLC activation by glutamate significantly The coupling distance between $\mathrm{Ca}^{2+}$ sources and $\mathrm{Ca}^{2+}$ sensors is a key determinant of signaling properties, and it can be probed by comparing the effects of BAPTA and EGTA. BAPTA, a fast $\mathrm{Ca}^{2+}$ chelator, effectively captures the $\mathrm{Ca}^{2+}$ on its way from the $\mathrm{Ca}^{2+}$ channels to the $\mathrm{Ca}^{2+}$ sensors in a short distance $(<100$ $\mathrm{nm})$, whereas EGTA, a slow $\mathrm{Ca}^{2+}$ chelator, selectively spares nanodomain $\mathrm{Ca}^{2+}$ signals (Neher, 1998; Eggermann and Jonas, 2012). Therefore, signal transmission is impaired by only BAPTA, but not by EGTA, when the coupling distance is short (nanodomain coupling), whereas both BAPTA and EGTA are effective when the coupling distance is longer ( $\mathrm{mi}$ crodomain coupling). We used the same experimental approach to probe the coupling distance between L-type $\mathrm{Ca}^{2+}$ channels and $\mathrm{Ca}^{2+}$ sensors involved in mGluR5-induced PLC activation. First,

simultaneous application of nimodipine $(10 \mu \mathrm{M})$ and mibefradil $(5 \mu \mathrm{M})$ had additive effect, inhibiting glutamate-induced $\left[\mathrm{Ca}^{2+}\right]_{\mathrm{i}}$ by $\sim 75 \%\left(\left[\mathrm{Ca}^{2+}\right]_{2} /\left[\mathrm{Ca}^{2+}\right]_{1}=25.0 \pm 5.3 \%, n=5, p<0.01\right)$. Interestingly, however, mibefradil did not inhibit glutamateinduced PH $\delta$-GFP translocation $\left(\Delta F_{2} / \Delta F_{1}=108.6 \pm 24.8 \%, n=\right.$ $6, p>0.05$; Fig. $3 B, E)$. We obtained similar results with another T-type $\mathrm{Ca}^{2+}$ channel blocker, $\mathrm{NiCl}_{2}\left(100 \mu \mathrm{M} ;\left[\mathrm{Ca}^{2+}\right]_{2} /\left[\mathrm{Ca}^{2+}\right]_{1}=\right.$ $53.5 \pm 4.4 \%, n=5, p<0.01 ; \Delta F_{2} / \Delta F_{1}=110.1 \pm 22.4 \%, n=5, p>$ 0.05; Fig. 3E).

The amplitude of glutamate-induced $\left[\mathrm{Ca}^{2+}\right]_{\mathrm{i}}$ or $\mathrm{PH} \delta$-GFP translocation was not significantly affected by $\omega$-conotoxin MVIIC $\left(1 \mu \mathrm{M} ;\left[\mathrm{Ca}^{2+}\right]_{2} /\left[\mathrm{Ca}^{2+}\right]_{1}=97.9 \pm 6.6 \%, n=5, p>0.05\right.$; $\left.\Delta F_{2} / \Delta F_{1}=94.4 \pm 6.3 \%, n=5, p>0.05\right)$, indicating that $\mathrm{N}$-type and $\mathrm{P} / \mathrm{Q}$ type $\mathrm{Ca}^{2+}$ channels are not involved (Fig. $3 C, E$ ). It was noted that 1-naphthyl acetyl spermine $(10 \mu \mathrm{M})$, a specific $\mathrm{Ca}^{2+}$ permeable AMPA blocker, slightly suppressed glutamate- we confirmed that the glutamate-induced increase in global $\mathrm{Ca}^{2+}$ was almost completely abolished in cultured hippocampal neurons loaded with BAPTA-AM $(100 \mu \mathrm{M})$ or EGTA-AM $(100 \mu \mathrm{M})$ for $30 \mathrm{~min}$ (data not shown). Nonetheless, the glutamateinduced translocation of $\mathrm{PH} \delta$-GFP was significantly inhibited in BAPTA-loaded cells $\left(\Delta F_{2} / \Delta F_{1}=45.4 \pm 7.0 \%, n=8, p<0.01\right)$, but was not affected significantly in EGTA-loaded cells $\left(\Delta F_{2} / \Delta F_{1}\right.$ $=69.3 \pm 7.9 \%, n=6, p>0.05 ; p<0.05$ with BAPTA-loaded cells) supporting the nanodomain coupling between L-type $\mathrm{Ca}^{2+}$ channels and the $\mathrm{Ca}^{2+}$ sensors involved in PLC activation (Fig. $4 A-C)$.

\section{Both $\mathrm{Ca}_{\mathrm{v}} 1.2$ and $\mathrm{Ca}_{\mathrm{v}} 1.3$ contribute to PLC activation} by glutamate

$\mathrm{Ca}_{\mathrm{v}} 1.2$ and $\mathrm{Ca}_{\mathrm{v}} 1.3$ are the most widely expressed L-type $\mathrm{Ca}^{2+}$ channels in neurons (Hell et al., 1993). We used an RNA inter- 
Aa
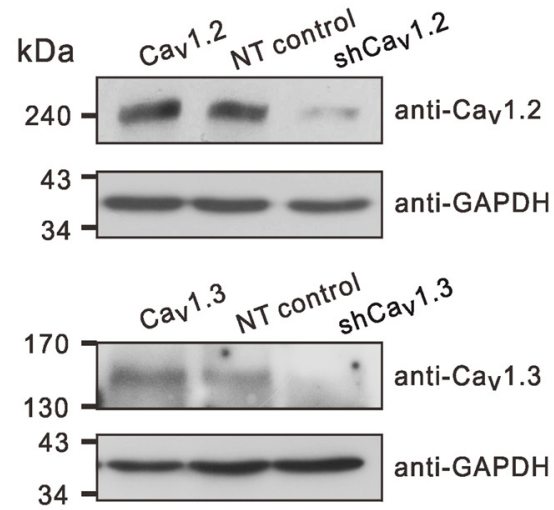

Ba

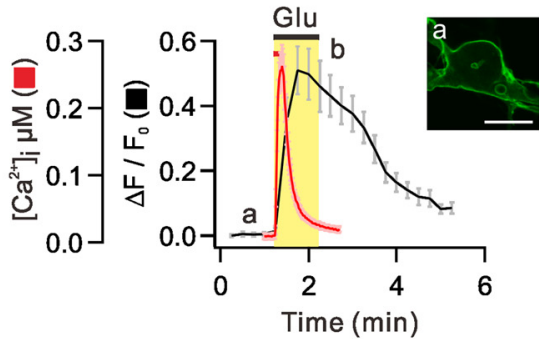

Bc

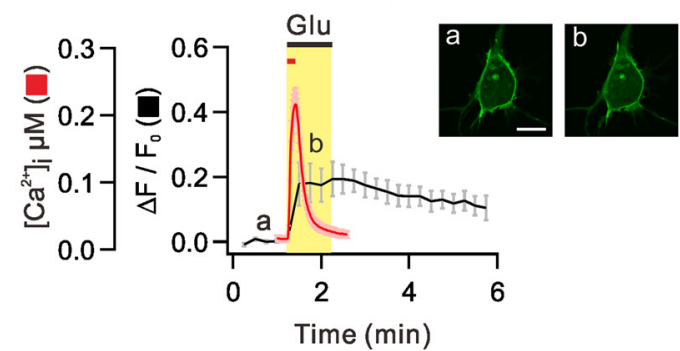

Ca

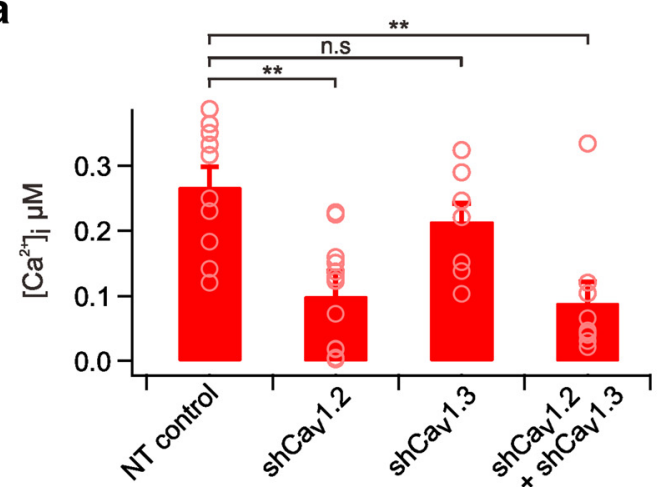

$A b$
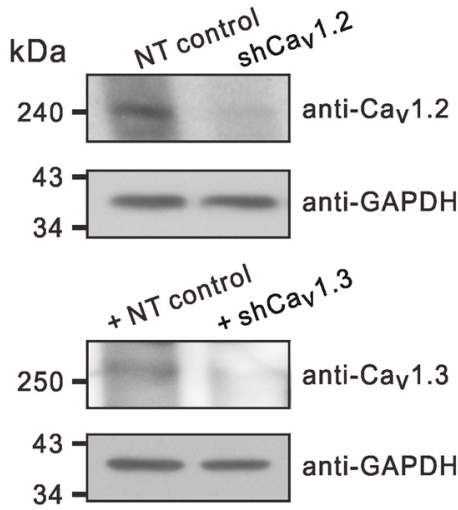

Bb

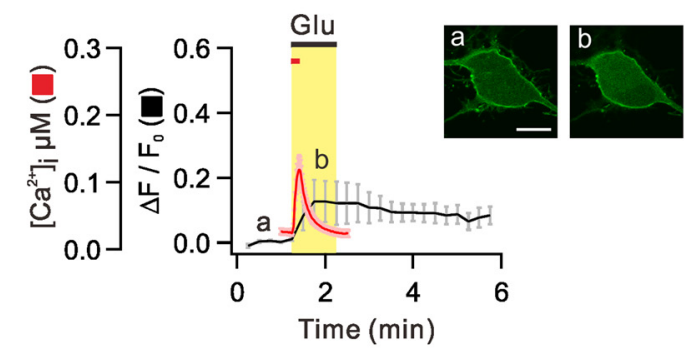

Bd

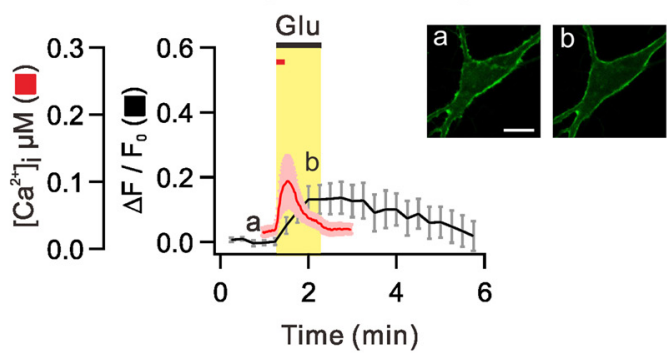

$\mathrm{Cb}$

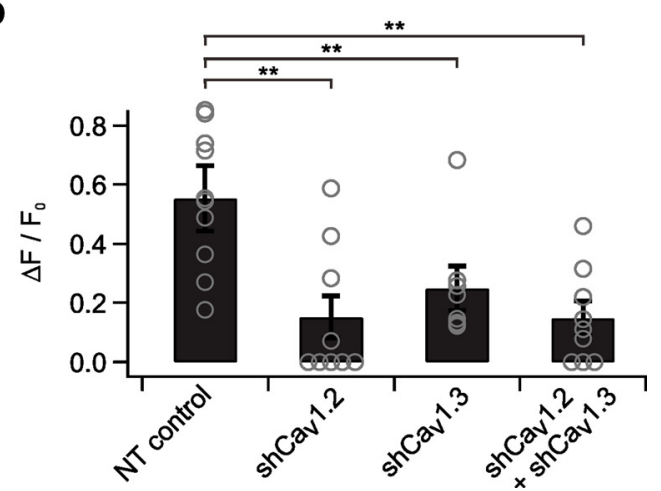

Figure 5. Both $\mathrm{Ca}_{v} 1.2$ and $\mathrm{Ca}_{v} 1.3$ contribute to glutamate-induced PH $\delta$-GFP translocation. Aa, Western blotting of overexpressed $\mathrm{Ca}_{v} 1.2$ (top) and $\mathrm{Ca}_{\mathrm{v}} 1.3$ (bottom) in HEK293 cells transfected with NT control, $\mathrm{Ca}_{v} 1.2$ shRNA (shCa 1.2 ), or $\mathrm{Ca}_{v} 1.3$ shRNA (shCa 1.3$)$. Ab, Western blotting of endogenous $\mathrm{Ca}_{\mathrm{v}} 1.2$ (top) and $\mathrm{Ca}_{\mathrm{v}} 1.3$ (bottom) in primary cultured hippocampal neurons transfected with NT control, shCa 1.2 , or shCa 1 1.3. GAPDH served as a loading control. Ba-Bc, Average of glutamate-induced $\left[\mathrm{Ca}^{2+}\right]_{\mathrm{i}}$ and $\Delta F / F_{0}$ are plotted against time in cells transfected with NT control, $\mathrm{shCa}_{\mathrm{v}} 1.2$, or shCa $\mathrm{a}_{\mathrm{v}}$ 1.3. The insets show representative images of PH $\delta$-GFP translocation at indicated time points $(\mathrm{a}, \mathrm{b})$. Scale bar, $10 \mu \mathrm{m}$. C, Bar graph summarizes $\left[\mathrm{Ca}^{2+}\right]_{\mathrm{i}}(\boldsymbol{C a})$ or $\Delta F / F_{0}(\boldsymbol{C b})$ for each group. n.s $p>0.05 ;{ }^{* *} p<0.01$. Error bars represent SEM.

ference technique to determine the contribution of $\mathrm{Ca}_{\mathrm{v}} 1.2$ and $\mathrm{Ca}_{\mathrm{v}} 1.3 \mathrm{Ca}^{2+}$ channels to the glutamate-induced $\mathrm{PH} \delta$-GFP translocation (see Materials and Methods). Immunoblot analyses of HEK293 cells or primary cultured hippocampal neu- rons transfected with respective DNA constructs revealed that the expression of both $\mathrm{Ca}_{\mathrm{v}} 1.2$ and $\mathrm{Ca}_{\mathrm{v}} 1.3$ was significantly decreased by targeted shRNAs compared with NT controls (Fig. 5Aa, $A b$ ). 
A
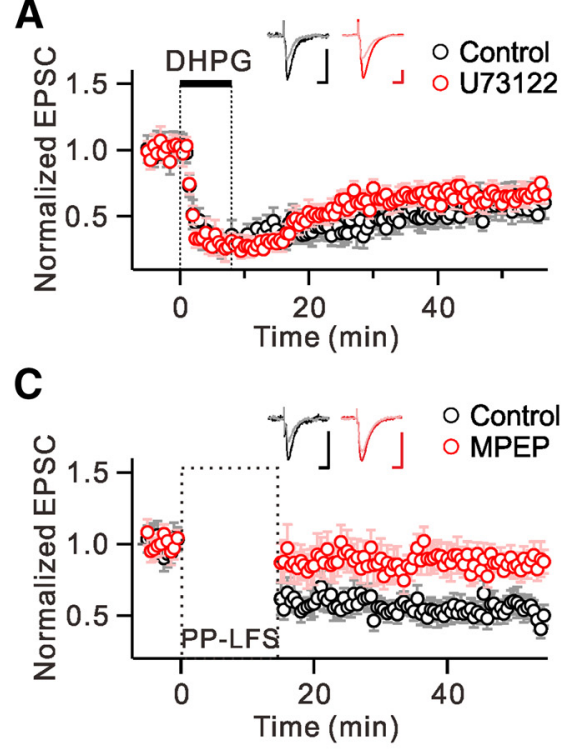

$\mathrm{Ea}$

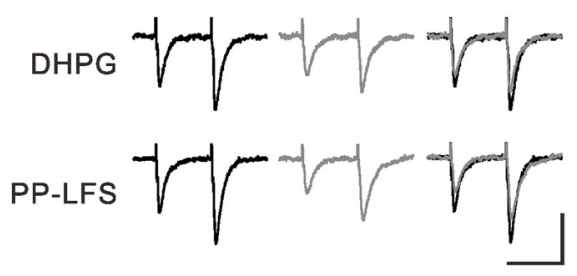

B
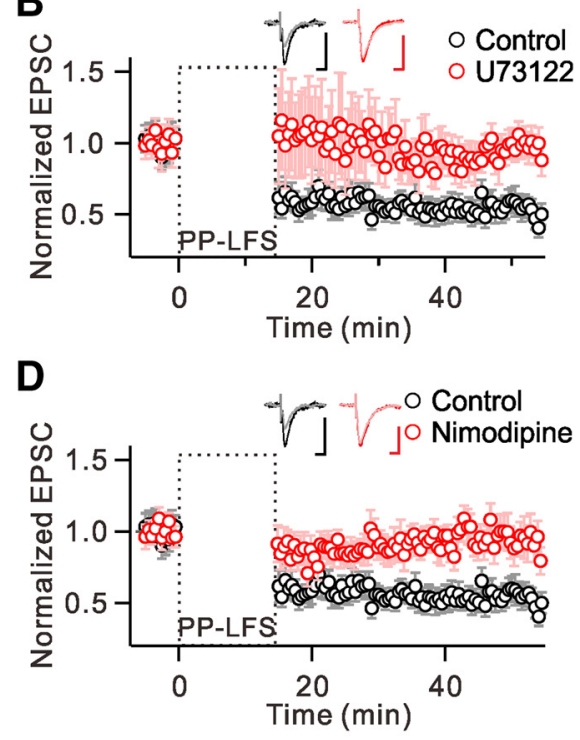

Eb

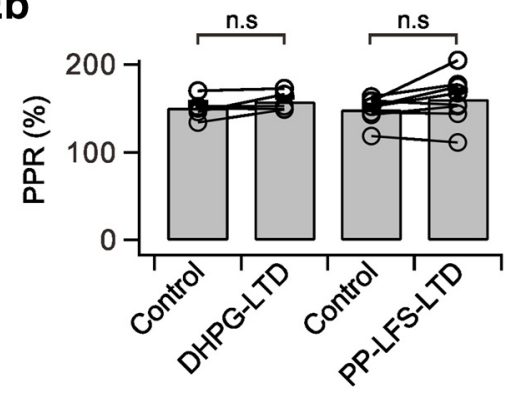

Figure 6. PLC is involved in mGluR-LTD induced by PP-LFS-LTD, but not in DHPG-LTD. EPSC amplitudes were normalized to the pre-DHPG or PP-LFS baseline values and were averaged. $A$, DHPG application induced a persistent depression of EPSC amplitude (black). Preincubation of slices in U73122 did not affect the magnitude of DHPG-LTD (red). The inset shows representative EPSCS during the baseline period (dark) and $40 \mathrm{~min}$ after (light) DHPG application in each condition. $\boldsymbol{B}$, PP-LFS induced a similar magnitude of LTD compared with DHPG-LTD (black). PP-LFS-LTD was significantly blocked by U73122 (red). C, Pharmacological blockade of mGluR5 by MPEP almost completely blocked PP-LFS-LTD (red). D, PP-LFS-LTD was blocked by nimodipine (red). Insets ( $\boldsymbol{B}-\boldsymbol{D})$ represent EPSCs during the baseline period (dark) and $35 \mathrm{~min}$ after (light) PP-LFS in each condition. Ea, Representative EPSCS elicited by paired-pulse stimulation (50 ms interval) during baseline (black, left) and after DHPG application or PP-LFS (gray, middle). Superimposed traces are shown in right panels. Scale bar, $50 \mathrm{~ms}$ (horizontal) and $100 \mathrm{pA}$ (vertical). Eb, Bar graphs summarize paired-pulse ratio (PPR) changes in each group. n.s $p>0.05$. Error bars represent SEM.

Glutamate-induced $\left[\mathrm{Ca}^{2+}\right]_{\mathrm{i}}$ remained unchanged up to $7 \mathrm{~d}$ following transfection of primary cultured dissociated hippocampal neurons with NT control, and the average $\left[\mathrm{Ca}^{2+}\right]_{\mathrm{i}}$ was $267.3 \pm 30.4 \mathrm{nM}(n=10)$ at $7 \mathrm{~d}$ post-transfection (dpt; Fig. $5 \mathrm{Ba}, \mathrm{Ca}$ ). It was noted that glutamate-induced $\left[\mathrm{Ca}^{2+}\right]_{\mathrm{i}}$ in neurons transfected with $\mathrm{Ca}_{\mathrm{v}} 1.2$-targeting shRNA $\left(\mathrm{shCa}_{\mathrm{v}} 1.2\right)$ was significantly decreased at $7 \mathrm{dpt}\left(\left[\mathrm{Ca}^{2+}\right]_{i}=99.7 \pm 21.4, n=14, p<\right.$ 0.01 ; Fig. $5 B b, C a)$. In contrast, glutamate-induced $\left[\mathrm{Ca}^{2+}\right]_{\mathrm{i}}$ measured in neurons transfected with $\mathrm{Ca}_{\mathrm{v}} 1.3$-targeting shRNA $\left(\mathrm{shCa}_{\mathrm{v}} 1.3\right)$ was slightly reduced, but was not significantly different from those transfected with NT control $\left(\left[\mathrm{Ca}^{2+}\right]_{\mathrm{i}}=215.0 \pm\right.$ $27.4, n=8, p>0.05$; Fig. $5 B c, C a)$. These data suggest that $\mathrm{Ca}_{\mathrm{v}} 1.2$ is the major isoform that mediates glutamate-induced $\mathrm{Ca}^{2+}$ influx compared with $\mathrm{Ca}_{\mathrm{v}} 1.3$.

Significant effects of $\mathrm{Ca}_{\mathrm{v}} 1.2$ knock-down on glutamateinduced $\mathrm{Ca}^{2+}$ increase were observed after $5 \mathrm{dpt}$. Thus, the effects of $\mathrm{Ca}_{\mathrm{v}} 1.2$ and $\mathrm{Ca}_{\mathrm{v}} 1.3$ knock-down on glutamate-induced $\mathrm{PH} \delta$ GFP translocation were tested in neurons between 6 and $8 \mathrm{dpt}$. The normalized average amplitude $\left(\Delta F / F_{0}\right)$ of the cytosolic fluorescence increment by glutamate in nontargeted cells was $0.55 \pm$ $0.07(n=10)$, and it was significantly decreased to $0.15 \pm 0.07$ $(n=9, p<0.01)$ in neurons transfected with $\operatorname{shCa}_{\mathrm{v}} 1.2$ (Fig. $5 B a, B b, C b$ ). The magnitude of inhibition by $\operatorname{shCa}_{\mathrm{v}} 1.2$ of glutamate-induced $\mathrm{PH} \delta$-GFP translocation was comparable to that of glutamateinduced $\mathrm{Ca}^{2+}$ increase. Interestingly, glutamate-induced $\mathrm{PH} \delta$-GFP translocation was also significantly reduced by $\operatorname{shCa}_{\mathrm{v}} 1.3\left(\Delta F / F_{0}=0.24 \pm 0.06, n=9, p<\right.$ 0.01 ; Fig. $5 B c, C b)$. Finally, the effects of $\mathrm{Ca}_{\mathrm{v}} 1.2$ and $\mathrm{Ca}_{\mathrm{v}} 1.3$ knock-down on $\mathrm{Ca}^{2+}$ transients $\left(\left[\mathrm{Ca}^{2+}\right]_{\mathrm{i}}=89.5 \pm 32.4, n=9\right.$, $p<0.01$; Fig. $5 B d, C a)$ and $\mathrm{PH} \delta$-GFP translocation $\left(\Delta F / F_{0}=0.15 \pm 0.05, n=\right.$ $9, p<0.01$; Fig. $5 B d, C b$ ) were comparable to the effects of $\mathrm{Ca}_{\mathrm{v}} 1.2$ knock-down alone. These data predict that the magnitude of $\mathrm{Ca}^{2+}$ influx is much larger for $\mathrm{Ca}_{\mathrm{v}} 1.2$ than for $\mathrm{Ca}_{\mathrm{v}} 1.3$, but both subtypes contribute to PLC activation by mGluR5.

mGluR-LTD is dependent on PLC and L-type $\mathrm{Ca}^{2+}$ channels at SC-CA1 pyramidal neuron excitatory synapse We now have evidence that DHPG is not sufficient to activate PLC in hippocampal neurons, which may be a clue for answering the question why mGluRLTD induced by DHPG (DHPG-LTD) is independent of PLC, $\mathrm{PKC}, \mathrm{IP}_{3}$, and postsynaptic $\mathrm{Ca}^{2+}$ (Schnabel et al., 1999; Fitzjohn et al., 2001; Mockett et al., 2011). We confirmed that DHPG-LTD is not affected by the PLC inhibitor U73122 (Control: $59.9 \pm 5.8 \%$ of baseline at $40 \mathrm{~min}$ after $100 \mu \mathrm{M}$ DHPG, $n=5$; U73122: $64.7 \pm 3.7 \%$ of baseline at $40 \mathrm{~min}$ after $100 \mu \mathrm{M}$ DHPG in the presence of $10 \mu \mathrm{M}$ U73122, $n=5, p>0.05$; Fig. $6 A$ ).

It should be noted that mGluR-LTD induced by PP-LFS (PP-LFS-LTD) was demonstrated to involve PLC and PLCdependent signal pathways (e.g., PKC and postsynaptic $\mathrm{Ca}^{2+}$; Bolshakov and Siegelbaum, 1994; Oliet et al., 1997; Otani and Connor, 1998; Reyes-Harde and Stanton, 1998; Lee et al., 2005; Holbro et al., 2009). Possibly, PP-LFS to SC fibers induces $\mathrm{Ca}^{2+}$ channel activation associated with action potentials or dendritic $\mathrm{Ca}^{2+}$ spikes, thus contributing to PLC activation. To test this idea, we examined the effects of blocking PLC or $\mathrm{Ca}^{2+}$ channels on the changes of EPSC amplitude induced by PP-LFS ( $1 \mathrm{~Hz}$ for $15 \mathrm{~min}$ ), which consistently induces mGluR-LTD (Lüscher and Huber, 2010). To inhibit NMDAR-dependent LTD, all recordings were performed in the presence of $50 \mu \mathrm{M} \mathrm{APV}$. We confirmed that after PP-LFS to SC fibers, EPSC amplitude was significantly reduced and this reduction lasted as long as the recording was maintained $(52.4 \pm 3.7 \%$ of baseline at $35 \mathrm{~min}$ after PP-LFS, $n=8$; Fig. $6 B-D)$. The induction of LTD by PP-LFS was prevented by $10 \mu \mathrm{M}$ U73122 $(98.2 \pm 2.3 \%$ of baseline at $35 \mathrm{~min}$ after PP-LFS, $n=6, p<0.01$; Fig. $6 B$ ). We also confirmed that mGluR-LTD induced by PP-LFS is almost completely suppressed by MPEP $(86.3 \pm 6.0 \%$ of baseline at $35 \mathrm{~min}$ after PP-LFS, $n=6$, $p<0.01$; Fig. $6 C$ ). We confirmed that the paired-pulse ratio remained unchanged by DHPG-LTD (Control: $150.4 \pm 5.8 \%$; 
DHPG-LTD: $157.8 \pm 4.9 \%, n=5, p>0.05)$ and PP-LFS-LTD (Control: $148.8 \pm 5.0 \%$; PP-LFS-LTD: $160.7 \pm 9.7 \%, n=8, p>$ 0.05 ; Fig. $6 E a, E b)$. These findings demonstrate that mGluR-LTD induced by PP-LFS of SC axons onto the CA1 pyramidal neurons requires PLC activation.

Finally, we tested whether L-type $\mathrm{Ca}^{2+}$ channels, which provide $\mathrm{Ca}^{2+}$ for PLC activation, are required for mGluR-LTD. We found that in the presence of $20 \mu \mathrm{M}$ nimodipine, PP-LFS to SC pathway did not induce LTD $(92.0 \pm 5.8 \%$ of baseline at $35 \mathrm{~min}$ after PP-LFS, $n=7, p<0.01$; Fig. $6 D$ ). Together, these findings demonstrate that mGluR-LTD at SC-CA1 synapses induced by PP-LFS involves PLC activation, and $\mathrm{Ca}^{2+}$ influx via $\mathrm{L}$-type $\mathrm{Ca}^{2+}$ channels serves as a prerequisite.

\section{Discussion}

In the present study, we demonstrated that mGluR5 stimulation is not sufficient for PLC activation in hippocampal neurons, but that $\mathrm{Ca}^{2+}$ influx via the L-type $\mathrm{Ca}^{2+}$ channels following AMPA receptor stimulation/membrane depolarization facilitates PLC activation. In addition, we found evidence that the coupling distance between L-type $\mathrm{Ca}^{2+}$ channels and $\mathrm{Ca}^{2+}$ sensors involved in PLC activation is very short $(<100 \mathrm{~nm})$. Finally, we have demonstrated the physiological significance of our findings by directly showing the involvement of PLC exclusively in PP-LFSLTD at SC-CA1 synapses. Given that mGluR-LTD represents a decrease in AMPA receptor activity by group I mGluRs (Lüscher and Huber, 2010), it is interesting to note that AMPA receptors initiate $\mathrm{Ca}^{2+}$ influx, which facilitates mGluR5/PLC signaling, and this leads to a long-lasting decrease of AMPA receptor activity, which may be regarded as a negative feedback from mGluRs to AMPA receptors. Our data provide novel insight into the interaction between AMPA receptors and group I mGluRs as well as the $\mathrm{Ca}^{2+}$ dependence of mGluR5-PLC signaling cascades in hippocampal neurons.

$\mathrm{Ca}^{2+}$ dependence of PLC activation by group I mGluRs and muscarinic receptors was previously reported (Masgrau et al., 2000, 2001; Hashimotodani et al., 2005; Maejima et al., 2005). In cerebellar granule cells, activation of PLC by glutamate, which is mediated by mGluR1, was dependent on the external $\mathrm{Ca}^{2+}$ (Masgrau et al., 2001), whereas muscarinic receptor-mediated activation of PLC was modulated by changes in the loading state of intracellular $\mathrm{Ca}^{2+}$ stores (Masgrau et al., 2000). These results suggest that the $\mathrm{Ca}^{2+}$ source facilitating PLC activation is specific to each receptor. Notably, these results are consistent with the idea that receptor-mediated PLC activation is regulated by local $\mathrm{Ca}^{2+}$. However, the specific $\mathrm{Ca}^{2+}$ source to induce local $\mathrm{Ca}^{2+}$ increase remained unclear. In the present study, we excluded the involvement of $\mathrm{Ca}^{2+}$ stores in glutamate-induced PLC activation by showing that thapsigargin affected neither glutamate-induced $\left[\mathrm{Ca}^{2+}\right]_{\mathrm{i}}$ increase nor PH $\delta$-GFP translocation (Fig. 2). From the effects of $\mathrm{Ca}^{2+}$ removal, we confirmed the role of $\mathrm{Ca}^{2+}$ influx in glutamate-induced $\left[\mathrm{Ca}^{2+}\right]_{\mathrm{i}}$ increase and PLC activation, and investigated the involvement of specific $\mathrm{Ca}^{2+}$ influx pathways. Both L-type and T-type $\mathrm{Ca}^{2+}$ currents contribute similarly to glutamate-induced $\mathrm{Ca}^{2+}$ influx (Fig. 3), which is consistent with previous studies showing abundant expression of $\mathrm{L}$-type $\left(\mathrm{Ca}_{\mathrm{v}} 1.2\right.$ and $\left.\mathrm{Ca}_{\mathrm{v}} 1.3\right)$ and T-type $\left(\mathrm{Ca}_{\mathrm{v}} 3.1, \mathrm{Ca}_{\mathrm{v}} 3.2\right.$, and $\left.\mathrm{Ca}_{\mathrm{v}} 3.3\right) \mathrm{Ca}^{2+}$ channels in the soma and proximal dendrites of hippocampal neurons (McKay et al., 2006; Leitch et al., 2009). Interestingly, however, only L-type $\mathrm{Ca}^{2+}$ channels contribute to PLC activation (Figs. 3, 5). The discrepancy between the contribution of each $\mathrm{Ca}^{2+}$ channel to global $\mathrm{Ca}^{2+}$ and its contribution to PLC activation supports the local $\mathrm{Ca}^{2+}$ dependence of mGluR5-mediated PLC activation in hippocampal neurons. In addition, BAPTA was more effective than EGTA at inhibiting mGluR-mediated PLC activation (Fig. 4), which confirms the nanodomain coupling between L-type $\mathrm{Ca}^{2+}$ channels and $\mathrm{Ca}^{2+}$ sensors involved in PLC activation. It needs to be noted that both glutamate-induced $\mathrm{Ca}^{2+}$ increases and $\mathrm{PH} \delta$-GHP translocation were completely abolished in $\mathrm{Ca}^{2+}$-free solutions, but the inhibition of L-type $\mathrm{Ca}^{2+}$ channels did not result in complete inhibition. These results suggest the presence of another $\mathrm{Ca}^{2+}$ entry pathway that couples to PLC activation.

Among members of the L-type $\mathrm{Ca}^{2+}$ channel subfamily $\left(\mathrm{Ca}_{\mathrm{v}} 1.1\right.$ to $\left.\mathrm{Ca}_{\mathrm{v}} 1.4\right), \mathrm{Ca}_{\mathrm{v}} 1.2$ and $\mathrm{Ca}_{\mathrm{v}} 1.3$ channels are expressed in neurons. They are often present in the same cell, but accumulating evidence shows that they play differential roles (Berger and Bartsch, 2014). Using hippocampal neurons derived from genetically modified mice that either lack $\mathrm{Ca}_{\mathrm{v}} 1.3$ or express dihydropyridine-insensitive $\mathrm{Ca}_{\mathrm{v}} 1.2$, researchers found that $\mathrm{Ca}_{\mathrm{v}} 1.2$ and $\mathrm{Ca}_{\mathrm{v}} 1.3$ provide $\mathrm{Ca}^{2+}$ influx that is coupled to distinct $\mathrm{Ca}^{2+}$-dependent conductance (Hasreiter et al., 2014). Since there are no pharmacological drugs that are selective for either the $\mathrm{Ca}_{\mathrm{v}} 1.2$ or the $\mathrm{Ca}_{\mathrm{v}} 1.3$ isoform, shRNA for each isoform was used to investigate whether the specific L-type $\mathrm{Ca}^{2+}$ channel subunits provide local $\mathrm{Ca}^{2+}$ for PLC activation by mGluR5 (Fig. 5). Inhibition of $\mathrm{Ca}^{2+}$ response by shCa 1.2 was large (63\% reduction) and significant, while the effect of $\mathrm{shCa}_{\mathrm{v}} 1.3$ was not significant. The effect of knock-down of both subunits was not different from the effect of $\mathrm{shCa}_{\mathrm{v}} 1.2$ alone, suggesting that $\mathrm{Ca}_{\mathrm{v}} 1.2$ is the major isoform that mediates L-type $\mathrm{Ca}^{2+}$ currents. Furthermore, inhibition of $\mathrm{PH} \delta$-GFP translocation by $\mathrm{shCa}_{\mathrm{v}} 1.2$ (73\% reduction) was comparable to its effect on $\mathrm{Ca}^{2+}$ response, supporting the idea that close coupling between $\mathrm{Ca}_{\mathrm{v}} 1.2$ and PLC underlies the observed $\mathrm{Ca}^{2+}$ dependence of glutamate-induced PLC activation. This idea is consistent with results from a recent study showing that mGluR5 physically interacts with $\mathrm{Ca}_{\mathrm{v}} 1.2$ subunits in hippocampal neurons (Kato et al., 2012). It was surprising, however, to find that $\operatorname{shCa}_{\mathrm{v}} 1.3$, which showed little effect on $\mathrm{Ca}^{2+}$ response, significantly inhibited glutamate-induced $\mathrm{PH} \delta$ GFP translocation (55\% reduction), suggesting a significant role of $\mathrm{Ca}_{\mathrm{v}} 1.3$ in PLC activation. However, the effect of $\operatorname{shCa}_{\mathrm{v}} 1.3$ on PH $\delta$-GFP translocation was not added to the effect of $\mathrm{shCa}_{\mathrm{v}} 1.2$ in double-knock-down experiments. These results may suggest that $\mathrm{Ca}_{\mathrm{v}} 1.3$ is involved in glutamate-induced PLC activation, but not as a $\mathrm{Ca}^{2+}$ source. We know of no molecular mechanisms that might account for the $\mathrm{Ca}^{2+}$-independent role of $\mathrm{Ca}_{\mathrm{v}} 1.3$, but such possibility needs to be explored in future studies.

We found that DHPG alone fails to induce $\mathrm{PH} \delta$-GFP translocation (Fig. 1A), but this finding does not necessarily mean that DHPG fails to activate PLC at all. When PLC activity was assessed by measuring the accumulation of ${ }^{3} \mathrm{H}$-labeled inositol monophosphate and polyphosphate $\left({ }^{3} \mathrm{H}-\mathrm{InsPs}\right)$, DHPG increased ${ }^{3} \mathrm{H}$ InsPs accumulation by 2-3-fold compared with the basal level (Alagarsamy et al., 2002, 2005). Admittedly, inositol phosphate (IP) formation assay using ${ }^{3} \mathrm{H}$-InsPs accumulation is a very sensitive measure of PLC activity: even the basal level of PLC activity is detected and the effects of agonists on PLC activation are expressed as fold increases in ${ }^{3} \mathrm{H}$-InsPs accumulation. In contrast, the change in basal level or DHPG-induced increase is hardly detected by the fluorescence-based assay using PH $\delta$-GFP translocation, suggesting that the sensitivity of this method may not be as high as ${ }^{3} \mathrm{H}$-InsPs accumulation measurement. Thus, the lack of PH $\delta$-GFP translocation by DHPG does not mean that DHPG has no effect, but that PH $\delta$-GFP translocation assay is not sensitive enough to detect small changes. In fact, previous results ob- 
tained from the IP formation assay do not contradict but rather agree with our results: DHPG and glutamate increased ${ }^{3} \mathrm{H}$-InsPs accumulation to 362 and $1344 \%$ of the basal level, respectively (Masgrau et al., 2001). The merit of $\mathrm{PH} \delta$-GFP translocation assay is that we can monitor dynamic changes at the single-cell level to investigate underlying mechanisms of PLC activation. Another method for detecting PLC activation from single cells is to use the canonical transient receptor potential channel 6 (TRPC6) as a biosensor (Hashimotodani et al., 2005), since TRPC6 is activated by DAG (Delmas et al., 2002; Hashimotodani et al., 2005). With this method, activation of TRPC6 by DHPG application was detected in hippocampal neurons (Hashimotodani et al., 2005), suggesting that TRPC6 activation is a more sensitive method than $\mathrm{PH} \delta$-GFP translocation for detecting PLC activation. However, the limitation to TRPC6 channels is that they serve as $\mathrm{Ca}^{2+}$ permeating channels. In fact, overexpression of TRPC6 caused $\mathrm{Ca}^{2+}$ overload (Kuwahara et al., 2006). Therefore, the overexpression of TRPC6 in hippocampal neurons may have provided $\mathrm{Ca}^{2+}$ influx to promote mGluR-mediated PLC activation. In this respect, TRPC6 may not be suitable as a biosensor for investigating $\mathrm{Ca}^{2+}$ sources for PLC activation.

mGluR-LTD has been linked to the etiology of multiple neurological and/or psychological diseases (e.g., mental retardation, autism, Alzheimer's disease, Parkinson's disease, and drug addiction; Lüscher and Huber, 2010; Ménard and Quirion, 2012). It is well established that mGluR-LTD in the cerebellum is dependent on PLC activation (Kano et al., 2008). Cerebellar mGluR-LTD requires both parallel fiber stimulation and the depolarization of Purkinje cell (postsynaptic) membranes (Kano et al., 2008). Likewise, when hippocampal mGluR-LTD was induced by PP-LFS of SC (i.e., when released glutamate depolarizes the postsynaptic membrane via AMPA receptors), mGluR-LTD consistently required postsynaptic $\mathrm{Ca}^{2+}$ (either $\mathrm{Ca}^{2+}$ mobilization or $\mathrm{Ca}^{2+}$ influx), PKC, and PLC (Bolshakov and Siegelbaum, 1994; Oliet et al., 1997; Otani and Connor, 1998; Reyes-Harde and Stanton, 1998; Lee et al., 2005; Holbro et al., 2009). In contrast, DHPGLTD was found to be independent of postsynaptic $\mathrm{Ca}^{2+}, \mathrm{PKC}$, and PLC (Schnabel et al., 1999; Fitzjohn et al., 2001; Mockett et al., 2011). Therefore, we suggest that mGluR-LTD in physiological conditions requires PLC, whereas chemical LTD (DHPGLTD) may bypass PLC activation and use alternative signaling pathways.

In summary, we have demonstrated in this study the importance of AMPA receptor-initiated $\mathrm{Ca}^{2+}$ influx via L-type $\mathrm{Ca}^{2+}$ channels in PLC activation by mGluR5 in hippocampal neurons. We also confirmed that hippocampal mGluR-LTD, induced by the stimulation of SC fibers, is dependent on PLC. We propose that in physiological conditions glutamate activates both AMPA and metabotropic glutamate receptors and their downstream events interact with each other to ensure reliable PLC activation.

\section{References}

Abe T, Sugihara H, Nawa H, Shigemoto R, Mizuno N, Nakanishi S (1992) Molecular characterization of a novel metabotropic glutamate receptor mGluR5 coupled to inositol phosphate/ $\mathrm{Ca}^{2+}$ signal transduction. J Biol Chem 267:13361-13368. Medline

Alagarsamy S, Rouse ST, Junge C, Hubert GW, Gutman D, Smith Y, Conn PJ (2002) NMDA-induced phosphorylation and regulation of mGluR5. Pharmacol Biochem Behav 73:299-306. CrossRef Medline

Alagarsamy S, Saugstad J, Warren L, Mansuy IM, Gereau RWt, Conn PJ (2005) NMDA-induced potentiation of mGluR5 is mediated by activation of protein phosphatase $2 \mathrm{~B} /$ calcineurin. Neuropharmacology 49 [Suppl 1]:135-145. Medline

Aramori I, Nakanishi S (1992) Signal transduction and pharmacological characteristics of a metabotropic glutamate receptor, mGluR1, in transfected CHO cells. Neuron 8:757-765. CrossRef Medline

Berger SM, Bartsch D (2014) The role of L-type voltage-gated calcium channels Cav1.2 and Cav1.3 in normal and pathological brain function. Cell Tissue Res 357:463-476. CrossRef Medline

Bolshakov VY, Siegelbaum SA (1994) Postsynaptic induction and presynaptic expression of hippocampal long-term depression. Science 264: 1148-1152. CrossRef Medline

Conn PJ, Pin JP (1997) Pharmacology and functions of metabotropic glutamate receptors. Annu Rev Pharmacol Toxicol 37:205-237. CrossRef Medline

Delmas P, Wanaverbecq N, Abogadie FC, Mistry M, Brown DA (2002) Signaling microdomains define the specificity of receptor-mediated $\operatorname{Ins} \mathrm{P}(3)$ pathways in neurons. Neuron 34:209-220. CrossRef Medline

De Simoni A, Yu LM (2006) Preparation of organotypic hippocampal slice cultures: interface method. Nat Protoc 1:1439-1445. CrossRef Medline

Doherty AJ, Palmer MJ, Henley JM, Collingridge GL, Jane DE (1997) (RS)2-chloro-5-hydroxyphenylglycine (CHPG) activates mGlu5, but no mGlu1, receptors expressed in $\mathrm{CHO}$ cells and potentiates NMDA responses in the hippocampus. Neuropharmacology 36:265-267. CrossRef Medline

Eggermann E, Jonas P (2012) How the 'slow' Ca(2+) buffer parvalbumin affects transmitter release in nanodomain-coupling regimes. Nat Neurosci 15:20-22. Medline

El-Hassar L, Hagenston AM, D’Angelo LB, Yeckel MF (2011) Metabotropic glutamate receptors regulate hippocampal CA1 pyramidal neuron excitability via $\mathrm{Ca}(2)(+)$ wave-dependent activation of SK and TRPC channels. J Physiol 589:3211-3229. CrossRef Medline

Fitzjohn SM, Palmer MJ, May JE, Neeson A, Morris SA, Collingridge GL (2001) A characterisation of long-term depression induced by metabotropic glutamate receptor activation in the rat hippocampus in vitro. J Physiol 537:421-430. CrossRef Medline

Gamper N, Reznikov V, Yamada Y, Yang J, Shapiro MS (2004) Phosphatidylinositol 4,5-bisphosphate signals underlie receptor-specific Gq/11-mediated modulation of N-type $\mathrm{Ca}^{2+}$ channels. J Neurosci 24:10980-10992. CrossRef Medline

Hashimotodani Y, Ohno-Shosaku T, Tsubokawa H, Ogata H, Emoto K, Maejima T, Araishi K, Shin HS, Kano M (2005) Phospholipase Cbeta serves as a coincidence detector through its $\mathrm{Ca} 2+$ dependency for triggering retrograde endocannabinoid signal. Neuron 45:257-268. CrossRef Medline

Hasreiter J, Goldnagl L, Böhm S, Kubista H (2014) Cav1.2 and Cav1.3 L-type calcium channels operate in a similar voltage range but show different coupling to $\mathrm{Ca}(2+)$-dependent conductances in hippocampal neurons. Am J Physiol Cell Physiol 306:C1200-C1213. CrossRef Medline

Hell JW, Westenbroek RE, Warner C, Ahlijanian MK, Prystay W, Gilbert MM, Snutch TP, Catterall WA (1993) Identification and differential subcellular localization of the neuronal class $C$ and class D L-type calcium channel alpha 1 subunits. J Cell Biol 123:949-962. CrossRef Medline

Holbro N, Grunditz A, Oertner TG (2009) Differential distribution of endoplasmic reticulum controls metabotropic signaling and plasticity at hippocampal synapses. Proc Natl Acad Sci U S A 106:15055-15060. CrossRef Medline

Horowitz LF, Hirdes W, Suh BC, Hilgemann DW, Mackie K, Hille B (2005) Phospholipase $\mathrm{C}$ in living cells: activation, inhibition, $\mathrm{Ca} 2+$ requirement, and regulation of M current. J Gen Physiol 126:243-262. CrossRef Medline

Ireland DR, Abraham WC (2002) Group I mGluRs increase excitability of hippocampal CA1 pyramidal neurons by a PLC-independent mechanism. J Neurophysiol 88:107-116. Medline

Kaech S, Banker G (2006) Culturing hippocampal neurons. Nat Protoc 1:2406-2415. CrossRef Medline

Kano M, Hashimoto K, Tabata T (2008) Type-1 metabotropic glutamate receptor in cerebellar Purkinje cells: a key molecule responsible for longterm depression, endocannabinoid signalling and synapse elimination. Philos Trans R Soc Lond B Biol Sci 363:2173-2186. CrossRef Medline

Kato HK, Kassai H, Watabe AM, Aiba A, Manabe T (2012) Functional coupling of the metabotropic glutamate receptor, InsP3 receptor and L-type Ca2 + channel in mouse CA1 pyramidal cells. J Physiol 590:3019-3034. CrossRef Medline

Kim J, Dittgen T, Nimmerjahn A, Waters J, Pawlak V, Helmchen F, Schlesinger S, Seeburg PH, Osten P (2004) Sindbis vector SINrep(nsP2S726): a tool for rapid 
heterologous expression with attenuated cytotoxicity in neurons. J Neurosci Methods 133:81-90. CrossRef Medline

Kuwahara K, Wang Y, McAnally J, Richardson JA, Bassel-Duby R, Hill JA, Olson EN (2006) TRPC6 fulfills a calcineurin signaling circuit during pathologic cardiac remodeling. J Clin Invest 116:3114-3126. CrossRef Medline

Lee HK, Min SS, Gallagher M, Kirkwood A (2005) NMDA receptorindependent long-term depression correlates with successful aging in rats. Nat Neurosci 8:1657-1659. CrossRef Medline

Lee KH, Lee JS, Lee D, Seog DH, Lytton J, Ho WK, Lee SH (2012) KIF21Amediated axonal transport and selective endocytosis underlie the polarized targeting of NCKX2. J Neurosci 32:4102-4117. CrossRef Medline

Lee SH, Rosenmund C, Schwaller B, Neher E (2000) Differences in Ca2+ buffering properties between excitatory and inhibitory hippocampal neurons from the rat. J Physiol 525:405-418. CrossRef Medline

Leitch B, Szostek A, Lin R, Shevtsova O (2009) Subcellular distribution of L-type calcium channel subtypes in rat hippocampal neurons. Neuroscience 164:641-657. CrossRef Medline

Lüscher C, Huber KM (2010) Group 1 mGluR-dependent synaptic longterm depression: mechanisms and implications for circuitry and disease. Neuron 65:445-459. CrossRef Medline

Maejima T, Oka S, Hashimotodani Y, Ohno-Shosaku T, Aiba A, Wu D, Waku K, Sugiura T, Kano M (2005) Synaptically driven endocannabinoid release requires $\mathrm{Ca}^{2+}$-assisted metabotropic glutamate receptor subtype 1 to phospholipase $\mathrm{C} \beta 4$ signaling cascade in the cerebellum. J Neurosci 25:6826-6835. CrossRef Medline

Mannaioni G, Marino MJ, Valenti O, Traynelis SF, Conn PJ (2001) Metabotropic glutamate receptors 1 and 5 differentially regulate CA1 pyramidal cell function. J Neurosci 21:5925-5934. Medline

Masgrau R, Servitja JM, Sarri E, Young KW, Nahorski SR, Picatoste F (2000) Intracellular $\mathrm{Ca} 2+$ stores regulate muscarinic receptor stimulation of phospholipase C in cerebellar granule cells. J Neurochem 74:818-826. Medline

Masgrau R, Servitja JM, Young KW, Pardo R, Sarri E, Nahorski SR, Picatoste F (2001) Characterization of the metabotropic glutamate receptors mediating phospholipase $\mathrm{C}$ activation and calcium release in cerebellar granule cells: calcium-dependence of the phospholipase $\mathrm{C}$ response. Eur J Neurosci 13:248-256. CrossRef Medline

McKay BE, McRory JE, Molineux ML, Hamid J, Snutch TP, Zamponi GW, Turner RW (2006) $\mathrm{Ca}(\mathrm{V}) 3$ T-type calcium channel isoforms differentially distribute to somatic and dendritic compartments in rat central neurons. Eur J Neurosci 24:2581-2594. CrossRef Medline

Ménard C, Quirion R (2012) Group 1 metabotropic glutamate receptor function and its regulation of learning and memory in the aging brain. Front Pharmacol 3:182. Medline

Mockett BG, Guévremont D, Wutte M, Hulme SR, Williams JM, Abraham WC (2011) Calcium/calmodulin-dependent protein kinase II mediates group I metabotropic glutamate receptor-dependent protein synthesis and long-term depression in rat hippocampus. J Neurosci 31:7380-7391. CrossRef Medline

Nakamura T, Barbara JG, Nakamura K, Ross WN (1999) Synergistic release of $\mathrm{Ca} 2+$ from IP3-sensitive stores evoked by synaptic activation of mGluRs paired with backpropagating action potentials. Neuron 24:727737. CrossRef Medline

Nakamura T, Nakamura K, Lasser-Ross N, Barbara JG, Sandler VM, Ross WN (2000) Inositol 1,4,5-trisphosphate $\left(\mathrm{IP}_{3}\right)$-mediated $\mathrm{Ca}^{2+}$ release evoked by metabotropic agonists and backpropagating action potentials in hippocampal CA1 pyramidal neurons. J Neurosci 20:8365-8376. Medline

Neher E (1998) Vesicle pools and Ca2+ microdomains: new tools for understanding their roles in neurotransmitter release. Neuron 20:389-399. CrossRef Medline

Oliet SH, Malenka RC, Nicoll RA (1997) Two distinct forms of long-term depression coexist in CA1 hippocampal pyramidal cells. Neuron 18:969982. CrossRef Medline

Otani S, Connor JA (1998) Requirement of rapid Ca2+ entry and synaptic activation of metabotropic glutamate receptors for the induction of longterm depression in adult rat hippocampus. J Physiol 511:761-770. CrossRef Medline

Rebecchi MJ, Pentyala SN (2000) Structure, function, and control of phosphoinositide-specific phospholipase C. Physiol Rev 80:1291-1335. Medline

Reyes-Harde M, Stanton PK (1998) Postsynaptic phospholipase C activity is required for the induction of homosynaptic long-term depression in rat hippocampus. Neurosci Lett 252:155-158. CrossRef Medline

Rubinson DA, Dillon CP, Kwiatkowski AV, Sievers C, Yang L, Kopinja J, Rooney DL, Zhang M, Ihrig MM, McManus MT, Gertler FB, Scott ML, Van Parijs L (2003) A lentivirus-based system to functionally silence genes in primary mammalian cells, stem cells and transgenic mice by RNA interference. Nat Genet 33:401-406. CrossRef Medline

Ryan XP, Alldritt J, Svenningsson P, Allen PB, Wu GY, Nairn AC, Greengard $P$ (2005) The Rho-specific GEF Lfc interacts with neurabin and spinophilin to regulate dendritic spine morphology. Neuron 47:85-100. CrossRef Medline

Ryu SH, Suh PG, Cho KS, Lee KY, Rhee SG (1987) Bovine brain cytosol contains three immunologically distinct forms of inositolphospholipidspecific phospholipase C. Proc Natl Acad Sci U S A 84:6649-6653. CrossRef Medline

Schnabel R, Kilpatrick IC, Collingridge GL (1999) An investigation into signal transduction mechanisms involved in DHPG-induced LTD in the CA1 region of the hippocampus. Neuropharmacology 38:1585-1596. CrossRef Medline

Sohn JW, Lee D, Cho H, Lim W, Shin HS, Lee SH, Ho WK (2007) Receptorspecific inhibition of GABAB-activated $\mathrm{K}+$ currents by muscarinic and metabotropic glutamate receptors in immature rat hippocampus. J Physiol 580:411-422. CrossRef Medline

Sohn JW, Yu WJ, Lee D, Shin HS, Lee SH, Ho WK (2011) Cyclic ADP ribose-dependent $\mathrm{Ca} 2+$ release by group I metabotropic glutamate receptors in acutely dissociated rat hippocampal neurons. PloS One 6:e26625. CrossRef Medline

Várnai P, Balla T (1998) Visualization of phosphoinositides that bind pleckstrin homology domains: calcium- and agonist-induced dynamic changes and relationship to myo-[3H]inositol-labeled phosphoinositide pools. J Cell Biol 143:501-510. CrossRef Medline

Won H, Lee HR, Gee HY, Mah W, Kim JI, Lee J, Ha S, Chung C, Jung ES, Cho YS, Park SG, Lee JS, Lee K, Kim D, Bae YC, Kaang BK, Lee MG, Kim E (2012) Autistic-like social behaviour in Shank2-mutant mice improved by restoring NMDA receptor function. Nature 486:261-265. CrossRef Medline

Yuan B, Latek R, Hossbach M, Tuschl T, Lewitter F (2004) siRNA Selection Server: an automated siRNA oligonucleotide prediction server. Nucleic Acids Res 32:W130-W134. CrossRef Medline 